Acta Protozool. (2018) 57: 243-266 www.ejournals.eu/Acta-Protozoologica doi:10.4467/16890027AP.18.018.10094 PROTOZOOLOGICA

\title{
Centrohelid Heliozoans (Centroplasthelida Febvre-Chevalier et Febvre, 1984) from Different Types of Freshwater Bodies in the Middle Russian Forest-steppe
}

\author{
Kristina I. PROKINA ${ }^{1,3}$, Dmitry G. ZAGUMYONNYI ${ }^{1,2}$, Denis V. TIKHONENKOV ${ }^{1,3}$ \\ ${ }^{1}$ Papanin Institute for Biology of Inland Waters RAS, Borok, Yaroslavl region, Russia \\ ${ }^{2}$ Voronezh State University, Voronezh, Russia \\ ${ }^{3}$ Laboratory of Cellular and Molecular Protistology, Zoological Institute, RAS, Saint Petersburg, Russia
}

\begin{abstract}
Species diversity of centrohelid heliozoans in different types of freshwater bodies (forest lakes, floodplain lakes, sphagnum bogs, and river) in the Middle Russian forest-steppe was studied. The morphology of cell coverings (scales and spicules) were observed using scanning and transmission electron microscopy. A total of 20 species of centrohelid heliozoans from five families (Acanthocystidae, Pterocystidae, Raphidiophryidae, Raphidocystidae, and Choanocystidae) and six genera (Acanthocystis, Raineriophrys, Pterocystis, Raphidiophrys, Raphidocystis, and Choanocystis) as well as an unidentified Centrohelea species and a Heterophrys-like organism were found. Morphological descriptions and electron micrographs are provided. The most common species were Acanthocystis nichollsi, Raphidiophrys capitata, and a Heterophrys-like organism. The highest species diversity was observed in terrace forest lakes, whereas the lowest was seen in sphagnum bogs. Four species (Acanthocystis costata, A. elenazhivotovae, A. mikrjukovii, and A. spinosa) were found for the first time since their original description. Three species (Acanthocystis spinosa, Raphidiophrys capitata, and Pterocystis pulchra) are new records for Russia. The distribution of the observed morphospecies confirms the cosmopolitanism of many centrohelids and highlights the importance of the type of water body and microbiotope in forming the species composition. The obtained data on the morphology of studied scales supplements our knowledge of the intraspecific variability of centrohelid heliozoans.
\end{abstract}

Keywords: centrohelids, heliozoans, protists, morphology, electron microscopy, sphagnum bog, lake, river

Abbreviations: SEM - scanning electron microscopy; TEM - transmission electron microscopy.

\section{INTRODUCTION}

The centrohelid heliozoans is a monophyletic group of protists related to haptophytes (Burki et al., 2016). Centrohelid heliozoans have tangental and/or radial si-

Address for correspondence: Kristina I. Prokina, Papanin Institute for Biology of Inland Waters of Russian Academy of Sciences, 109, Borok, Nekouzskiy district, Yaroslavl Region, Russia, 142742; e-mail: kristin892@mail.ru liceous (rarely organic) scales, with the exception of one genus, Oxnerella, which lacks them. Centrohelids are obligate, passive predators, that float in the water or attach to a substrate and capture prey with axopodia. The morphology of centrohelids began to be actively studied with the spread of electron microscopy, begining in the second half of the 20th century (Nicholls 1983; Dürrschmidt 1985, 1987a, b; Croome 1986, 1987; Siemensma and Roijackers 1988a, b; Mikrjukov 1993a, b, 1999 2001, etc.). Electron microscopy is now required 
for the investigation of centrohelid diversity as the cell coverings are considered their main diagnostic feature.

Morphological studies are extremely important for organisms with asexual reproduction since their morphological variability and dimensional characteristics provide a greater understanding of the species concept in agamous protists. Only about 100 morphospecies of centrohelid heliozoans are known today. Many of them are rarely observed and little is known about their morphological variability and ecological distribution. Despite this, the descriptions of a new species are appearing constantly (Cavalier-Smith and von der Heyden 2007, Leonov 2010b, Tikhonenkov and Mylnikov 2011, Zlatogursky 2015, Zlatogursky et al. 2017). The diversity of the centrohelids has been studied unevenly, with some regions explored more intensively than others (Nicholls 1983, Croome 1986, Dürrschmidt 1987a, Leonov and Plotnikov 2009, Kosolapova and Mylnikov 2015, etc.). Most of the papers devoted to the diversity of centrohelid heliozoans lack detailed descriptions of the studied water bodies even though the characteristics of microbiotopes (type of the mire, the vegetation associated with the biotope, type of bottom sediment, hydrochemical parameters) are extremely important for understanding the distribution patterns of unicellular protists.

Previous investigations of centrohelid species diversity in the Middle Russian forest-steppe have revealed four new species of the genus Acanthocystis (Leonov 2010b) and eight new species records for Russia (Leonov 2009, 2010b; Leonov and Plotnikov 2009). These results highlight the potential for further studies on species diversity in that area.

The aim of our work was to study the species composition, distribution and morphology of cell coverings of centrohelid heliozoans in different types of freshwater bodies (lakes, sphagnum bogs, river) in Middle Russian forest-steppe by transmission and scanning electron microscopy.

\section{MATERIALS AND METHODS}

Water samples were taken from several different types of water bodies in the Middle Russian forest-steppe. The Usman Pine Forest area (Voronezh Region, Russia) was chosen as the location for our survey due to the presence of diverse yet typical water ecosystems for the Middle Russian forest-steppe that have well-studied hydrochemistry and hydrology and are exposed to only a weak anthropogenic influence as the territory is protected. It is a large typical forest in the Middle Russian forest-steppe located on 61000 hectares. The Usman Pine Forest occupies the Western outskirts of the Oka-Don plain, left bank of the Voronezh River and its tributaries (Khlyzova et al. 2007).

Four types of water bodies with different hydrochemical and hydrological regimes were observed in the studied area: sphagnum bogs, terrace forest lakes (supplied only by groundwater and precipitation but not riverine waters during floods), floodplain lakes, and a river. Sphagnum bogs are mesotrophic mires with mixed types of water supply. The chemical composition of all three sphagnum bogs is typical for boggy waters. Forest lakes are formed on similar landscapes within one active water system and share similar water chemical compositions. All the lakes possess the features of transitioning to the mire regime: low mineralization and $\mathrm{pH}$. Floodplain lakes are periodically flooded in the spring high water period and have a similar mineral composition to the water of the Usman' River (Zhivotova and Koroteeva 2002). Detailed characteristics of observed water bodies are present in Table 1 .

Several microbiotopes were studied in each water body. Samples were taken from mire lakes (with peat and detritus) and from hollows (with Sphagnum) within sphagnum bogs. The water column and two types of bottom sediments (plant debris and silt or sand) were sampled in other water bodies (see Table 2).

Samples were collected on August, 20-22, 2017. Water samples with and without bottom sediments or Sphagnum were placed into $50 \mathrm{ml}$ plastic tubes and transported to the laboratory at $4^{\circ} \mathrm{C}$. Samples were enriched with a suspension of Pseudomonas fluorescens Migula, 1895 bacteria and Bodo saltans Ehrenberg, 1838 flagellate cell culture, and placed in Petri dishes. Samples were kept at $22^{\circ} \mathrm{C}$ in the dark and observed for 10 days to reveal the cryptic species diversity (Vørs 1992). An AxioScope A1 light microscope (Carl Zeiss, Germany) with DIC and phase contrast and water immersion objectives (total magnification $\times 1120$ ) were used for observations of living cells. Electron microscope preparations were carried out according to described methods (Moestrup and Thomsen 1980, Mikrjukov 2002) and observed in a JEM-1011 (Jeol, Japan) transmission electron microscope and a JSM-6510 LV (Joel, Japan) scanning electron microscope. Heliozoans were picked from the samples cell by cell for SEM preparations. Concentrated samples were used for TEM preparations. The dendrogram showing the similarity of the water bodies by species composition was drawn on the basis of the Bray-Curtis similarity index using the single linkage algorithm in the PAST software package (Hammer et al. 2001).

\section{RESULTS}

Twenty species of centrohelid heliozoans from five families (Acanthocystidae, Pterocystidae, Raphidiophryidae, Raphidocystidae, and Choanocystidae) and six genera (Acanthocystis, Raineriophrys, Pterocystis, Raphidiophrys, Raphidocystis, and Choanocystis), as well as a Heterophrys-like organism and one unidentified species of Centrohelea, were observed. Morphological characteristics of investigated siliceous scales having an important diagnostic value, are listed below. The current centrohelid system (Zlatogursky et al. 2018, Adl et al. 2019) is used. The data on distribution of cen- 
Table 1. Characteristics of observed water bodies.

\begin{tabular}{|c|c|c|c|c|}
\hline Water bodies & Coordinates, N, E & $\mathrm{pH}$ & TDS, mg/l & $\mathrm{T},{ }^{\circ} \mathrm{C}$ \\
\hline \multicolumn{5}{|l|}{ Sphagnum bogs } \\
\hline Klukvennoye-1 & $51^{\circ} 48^{\prime} 56.7^{\prime \prime}, 39^{\circ} 23^{\prime} 37.6^{\prime \prime}$ & 4.8 & 41 & 19 \\
\hline Klukvennoye-2 & $51^{\circ} 48^{\prime} 56.9^{\prime \prime}, 39^{\circ} 23^{\prime} 38.4^{\prime \prime}$ & 5.2 & 118 & 25 \\
\hline Klukvennoye-3 & $51^{\circ} 49^{\prime} 32.7^{\prime \prime}, 39^{\circ} 25^{\prime} 08.8^{\prime \prime}$ & 5.0 & 60 & 28 \\
\hline \multicolumn{5}{|c|}{ Terraced forest lakes } \\
\hline Cherepashye & $51^{\circ} 49^{\prime} 12.4^{\prime \prime}, 39^{\circ} 24^{\prime} 38.7^{\prime \prime}$ & 6.7 & 70 & 28 \\
\hline Maklok & $51^{\circ} 48^{\prime} 31.0^{\prime \prime}, 39^{\circ} 24^{\prime} 50.6^{\prime \prime}$ & 7.6 & 71 & 29 \\
\hline Chistoye & $51^{\circ} 48^{\prime} 36.3^{\prime \prime}, 39^{\circ} 23^{\prime} 51.9^{\prime \prime}$ & 7.5 & 62 & 27 \\
\hline \multicolumn{5}{|l|}{ Floodplain lakes } \\
\hline Vosmerka & $51^{\circ} 48^{\prime} 45.4^{\prime \prime}, 39^{\circ} 22^{\prime} 54.2^{\prime \prime}$ & 8.1 & 256 & 23 \\
\hline Krugloye & $51^{\circ} 48^{\prime} 46.5^{\prime \prime}, 39^{\circ} 22^{\prime} 44.5^{\prime \prime}$ & 8.2 & 231 & 22 \\
\hline \multicolumn{5}{|l|}{ River } \\
\hline Usman' & $51^{\circ} 48^{\prime} 42.7^{\prime \prime}, 39^{\circ} 23^{\prime} 03.3^{\prime \prime}$ & 8.1 & 382 & 23 \\
\hline
\end{tabular}

trohelid species in observed water bodies and types of habitats are present in the Table 2. Morphometric characteristics of observed species and number of observed cells or scales for each type of water bodies and microbiotope are present in the supplemental Table S1.

DIAPHORETICKES Adl et al., 2012

Sar Burki et al., 2008, emend. Adl et al., 2012

*Haptista Cavalier-Smith, 2003

**Centroplasthelida Febvre-Chevalier et Febvre, 1984 2018

***Panacanthocystida Shishkin et Zlatogursky,

****Acanthocystidae Claus, 1874 emend. CavalierSmith et von der Heyden, 2007

Acanthocystis aff. amura Zlatogursky et al., 2017 (Fig. 2A-E)

Description: Spine scale consists of a straight cylindrical shaft and a circular flattened base. Shaft is 3.88$5.98 \mu \mathrm{m}$ in length, $0.12-0.21 \mu \mathrm{m}$ in diameter, base is $0.63-0.93 \mu \mathrm{m}$ in diameter. Tip of shaft divided into 4 rounded furcae (Fig. 2D) or hooks (Fig. 2C) $0.10-0.16$ $\mu \mathrm{m}$ in length. Oval plate scales are $1.98-2.47 \times 1.42$ $1.68 \mu \mathrm{m}$, with medial thickening $(0.75-1.51 \times 0.12-0.19$ $\mu \mathrm{m})$ and dense margins.

Remarks: A. amura was previously found only in the Far East and Orenburg Region, Russia (Zlatogursky et al. 2017). The presence of two types of spine scales was noted for this species: long spine scales (1.3-6.2 $\mu \mathrm{m})$ with rounded hooks on tips; short spine scales
(1.0-3.4 $\mu \mathrm{m})$ with $3-5$ pointed furcae. We observed only long spine scales with round hooks or round furcae. Morphology of plate scales agreed well with the original description.

Acanthocystis costata Zlatogursky, 2015 (Fig. 2F-I)

Description: Straight or slightly curved spine scales consist of a hollow shaft and circular base. Shaft is 5.0 $10.78 \mu \mathrm{m}$ in length and $0.29-0.34 \mu \mathrm{m}$ in diameter, base is $0.96-1.21 \mu \mathrm{m}$ in diameter. Tip of shaft divided on 4-6 furcae $(0.43-0.65 \mu \mathrm{m}$ in length). Oval plate scales are 3.18-3.78 $\times 1.59-2.15 \mu \mathrm{m}$, with concave lateral sides, medial thickening $(0.55-0.72 \mu \mathrm{m}$ in length) and dense margins. Some plate scales have numerous small granules (Fig. 2I), others are ornamented with about 50 short $(0.15-0.27 \mu \mathrm{m})$ radial slits (Fig. $1 \mathrm{H})$.

Remarks: This species was previously noted only once from the freshwater pool in the greenhouse of the botanical garden of St. Petersburg State University, St. Petersburg, Russia (Zlatogursky 2015). Morphology of observed scales completely corresponds with the original description.

Acanthocystis elenazhivotovae Leonov, 2010 (Fig. 2J-M)

Description: Spine scales consist of hollow cylindrical shaft and circular base. Shaft is $2.36-7.97 \mu \mathrm{m}$ in length, $0.16-0.22 \mu \mathrm{m}$ in diameter, base is $0.68-0.97$ $\mu \mathrm{m}$ in diameter. Tip of shaft divided on 3 short rounded furcae $(0.15-0.20 \mu \mathrm{m}$ in length). Oval plate scales are 
246 K. I. Prokina et al.

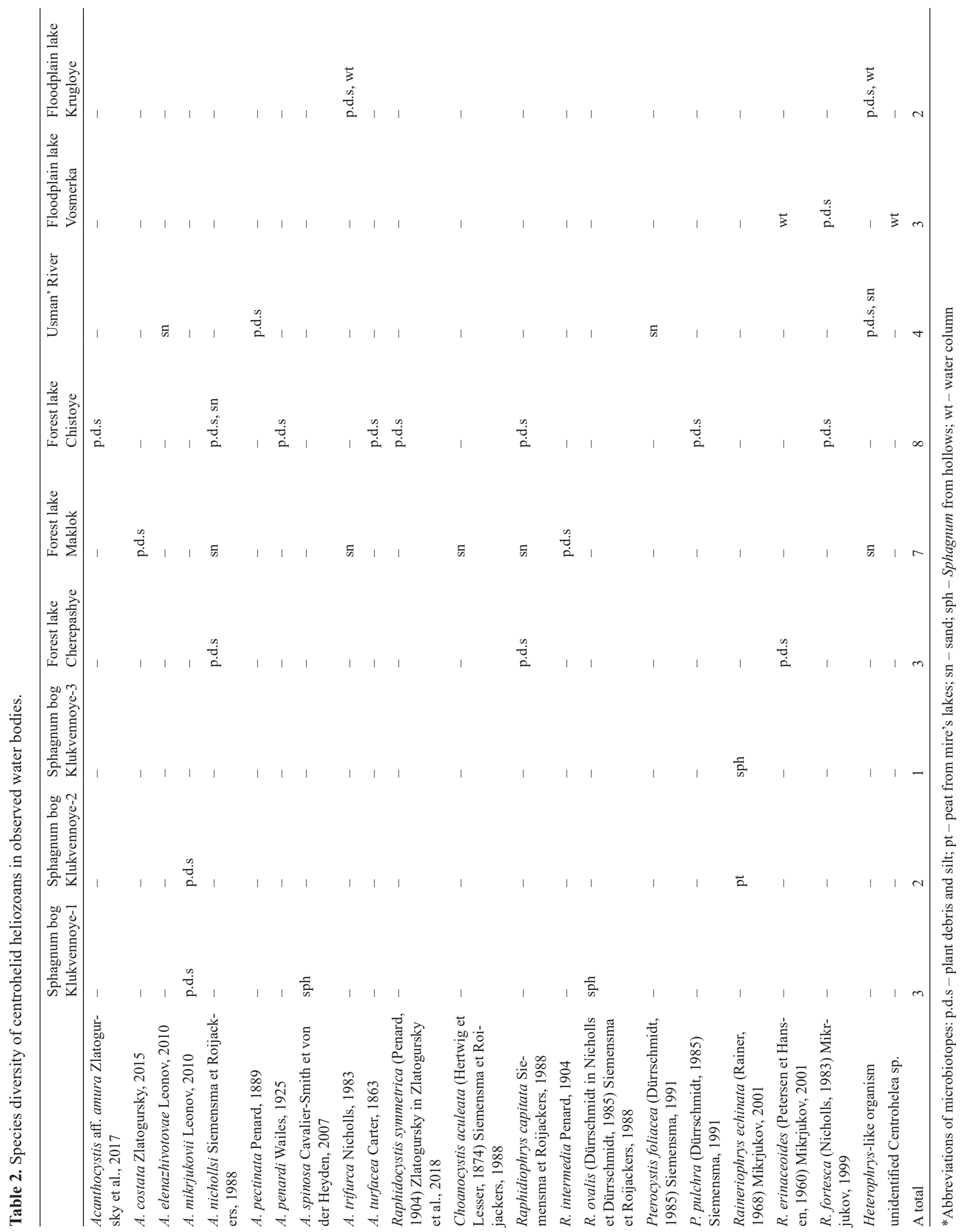



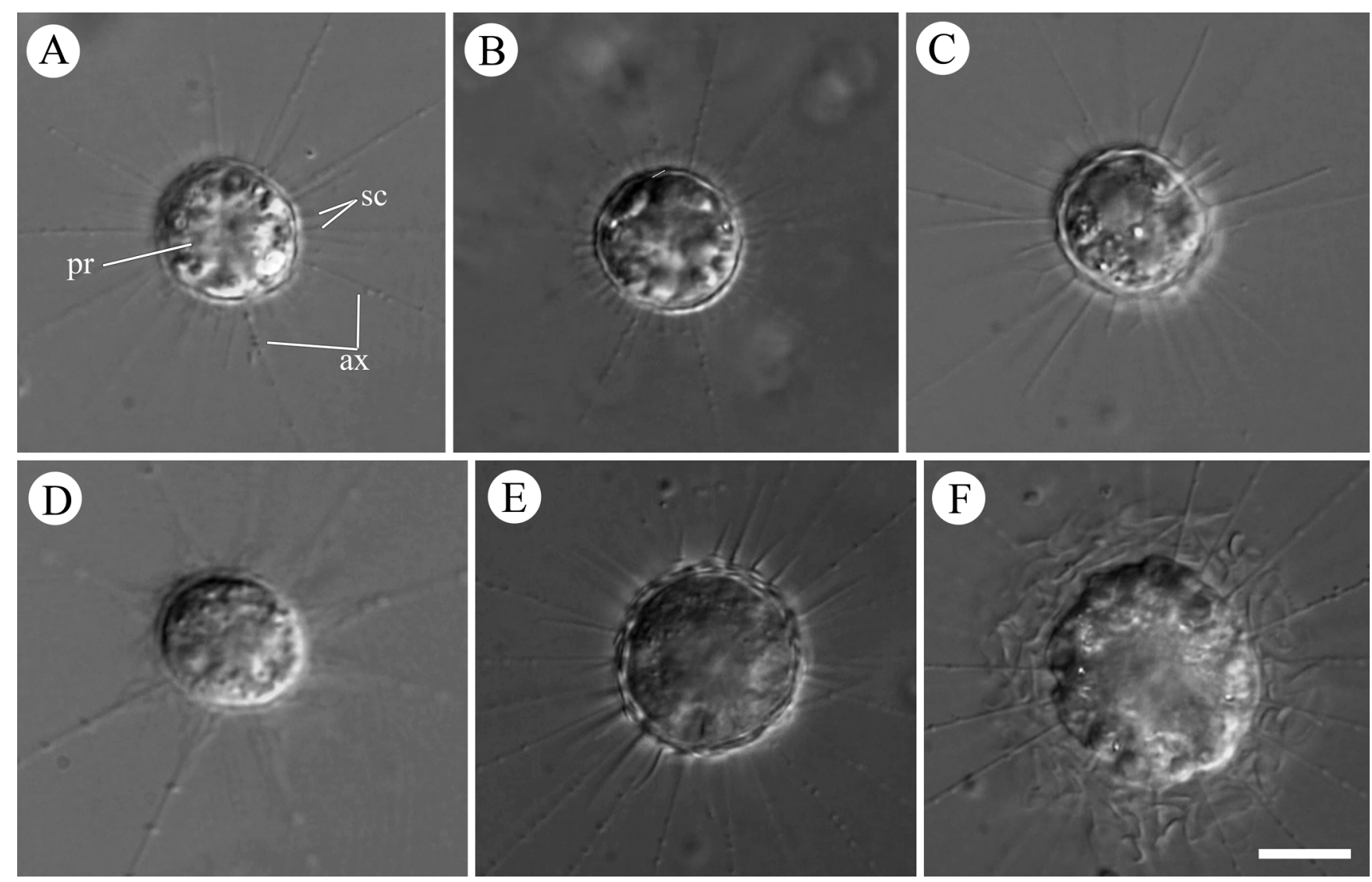

Fig. 1. Morphology of living cells of some observed centrohelid species (DIC): A - Acanthocystis nichollsi; B - A. pectinata (from plant debris and silt of Usman' River); C - A. turfacea (from plant debris and silt of Lake Chistoye); D - Raphidocystis symmetrica (from plant debris and silt of Lake Chistoye); E - Choanocystis aculeata (from sand of Lake Maklok); F - Raphidiophrys capitata (from sand of Lake Maklok). Abbreviations: ax - axopodia; pr - protoplast; sc - scales. Scale bar: $20 \mu \mathrm{m}$.

2.42-3.18 $\times 1.51-2.04 \mu \mathrm{m}$, with radial, branched ribs (Fig. 2M) $0.34-0.67 \mu \mathrm{m}$ in length, and medial thickening $(0.59-0.68 \mu \mathrm{m}$ in length).

Remarks: A. elenazhivotovae was previously noted only once from the waterlogged habitat of Yaroslavl Region, Russia (Leonov 2010b). Scales with 2 furcae were also observed but the possibility of a third hidden furca is not excluded. Morphology of observed scales corresponds to the original description, except with slightly larger sizes. Leonov noted spine scales length $3.2-6.0 \mu \mathrm{m}$, size of plate scales $2.5-2.8 \times 1.6-1.8 \mu \mathrm{m}$. Plate scales of this species are similar to plate scales of A. quadrifurca Nicholls, 1983, however, the last one has 4 pointed furcae on the tips of the spine scales.

Acanthocystis mikrjukovii Leonov, 2010 (Fig. 2N-Q)
Description: Spine scales consist of a hollow cylindrical shaft and circular base. Shaft is $2.50-6.84 \mu \mathrm{m}$ in length, $0.18-0.27 \mu \mathrm{m}$ in diameter, base is $0.66-0.93$ $\mu \mathrm{m}$ in diameter. Tip of shaft divided on 3 furcae $(0.28$ $0.47 \mu \mathrm{m}$ in length), each furca with 1 tooth on inner side (Fig. 2O, P). Pear-shaped plate scales are 2.01$2.74 \times 1.51-2.48 \mu \mathrm{m}$, with medial thickening $(0.43-0.72$ $\mu \mathrm{m}$ in length), and dense margins.

Remarks: This species was previously noted only once from the same locality (sphagnum bog Klukvennoye-1) (Leonov 2010b). Morphology of observed scales corresponds to the original description except for the smaller diameter of the base of spine scales. Observed scales are similar to A. takahashii Dürrschmidt, $1987 \mathrm{a}$, but spine scales of the last species contain membrane between the furcae and 1-4 teeth on the inner side 
248 K. I. Prokina et al.

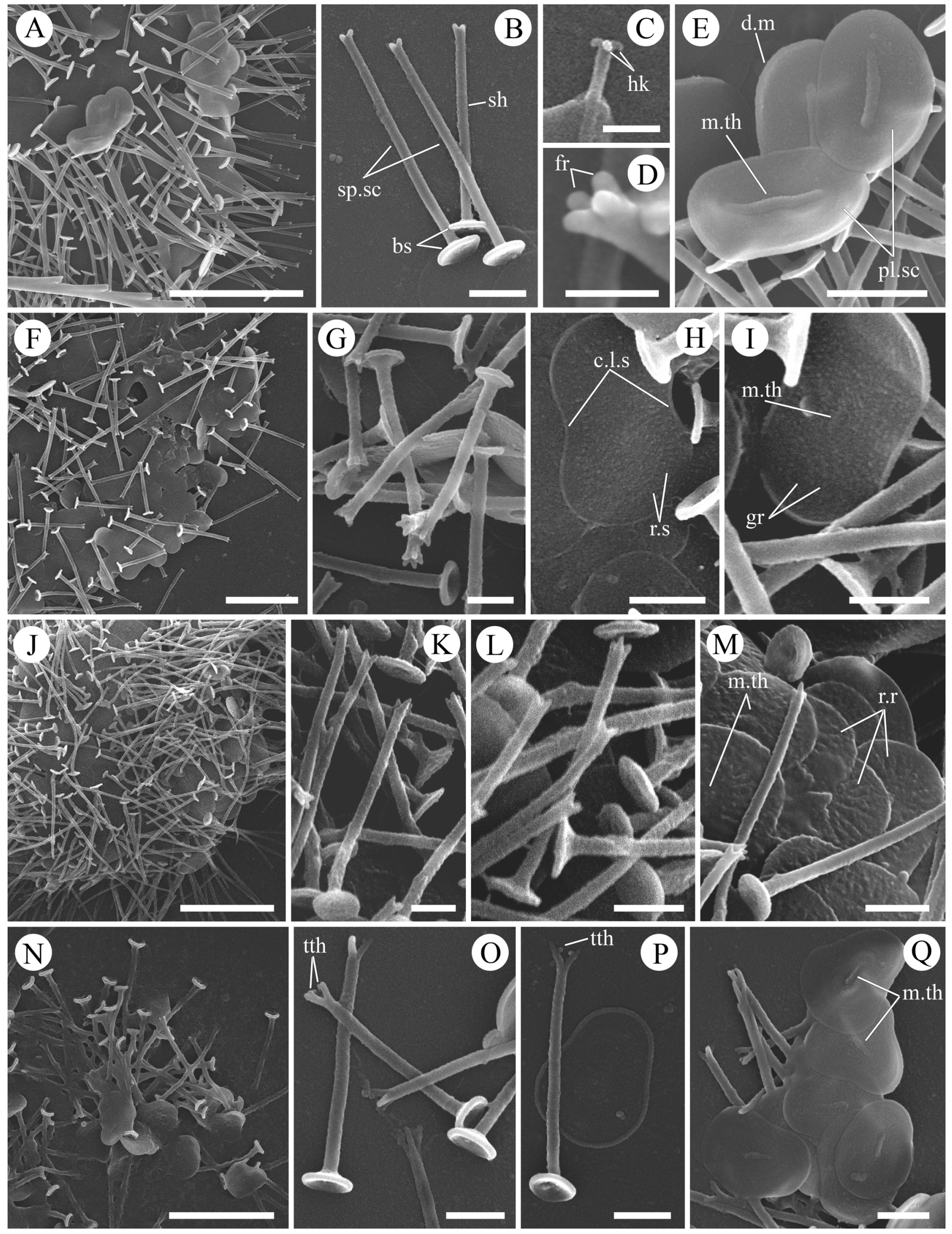


of furcae. In addition, plate scales of A. takahashii can be not only pear-shaped but also oval (Dürrschmidt 1987a).

Acanthocystis nichollsi Siemensma et Roijackers, 1988 [syn.: A. pectinata Penard, 1889 emend. Nicholls, 1983] (Figs 1A, 3A-D)

Description: Diameter of protoplast of living cells is $28-30 \mu \mathrm{m}$. Spine scales of two types (long and short), both consist of a hollow cylindrical shaft and circular base. Shaft is $0.20-0.30 \mu \mathrm{m}$ in diameter, tip divided on 4-6 furcae. Long spine scales are 4.13-10.95 $\mu \mathrm{m}$ in length, base is $0.89-1.22 \mu \mathrm{m}$ in diameter, furcae diverge on $0.42-0.67 \mu \mathrm{m}$. Short spine scales are $1.97-3.52 \mu \mathrm{m}$ in length, base is $0.62-0.93 \mu \mathrm{m}$ in diameter, furcae diverge on $0.60-1.35 \mu \mathrm{m}$ and connected by a membrane, forming a cup-shaped structure. Oval plate scales are 2.28-3.08 $\times 1.41-2.04 \mu \mathrm{m}$, with concave lateral sides, medial thickening $(0.50-0.86 \mu \mathrm{m}$ in length), radial slits (0.17-0.26 $\mu \mathrm{m}$ in length), and dense margins.

Remarks: Morphology of observed scales corresponds with previous descriptions, however, some authors noted larger plate scales $(3.8 \times 2.1 \mu \mathrm{m})$ (Leonov 2010a, Leonov and Mylnikov 2012, Kosolapova and Mylnikov 2015) and larger spine scales (up to $15 \mu \mathrm{m}$ ) (Leonov 2010a). Also, up to 8 furcae on short spine scales were described previously (Dürrschmidt 1987a, Leonov 2010a). This species is similar to A. pectinata Penard, 1889, A. polymorpha Dürrschmidt, 1985, A. siemensmae Gerasimova et Plotnikov, 2016, and A. valdiviense Dürrschmidt, 1987, but differs by the morphology of cup-shaped tips of short spine scales and presence of radial slits on plate scales (Mikrjukov 2002).

Distribution: Freshwaters of Europe (CavalierSmith and von der Heyden 2007), Asia (Kosolapova and Mylnikov 2015), N. America ([as A. pectinata] Nicholls 1983), S. America (Dürrschmidt 1987a, Prokina and Mylnikov 2019), Australia ([as A. pectinata] Croome 1986), New Zealand, Malaysia, Sri Lanka ([as A. pectinata] Dürrschmidt 1987a). It was found in Russia in freshwaters of European part (Leonov 2009, 2010a, Leonov and Mylnikov 2012), in saline inland waters of Orenburg Region (Gerasimova and Plotnikov 2015).

Acanthocystis pectinata Penard, 1889 emend. Siemensma et Roijackers, 1988 [syn.: Acanthocystis pectinata Penard, 1889 emend. Nicholls, 1983 ssp. ceylanica Dürrschmidt, 1987] (Figs 1B, 3E-I)

Description: Diameter of protoplast of living cells is $27-29 \mu \mathrm{m}$. Hollow cylindrical shaft of spine scales is $0.20-0.25 \mu \mathrm{m}$ in diameter. Long spine scales are 3.8 $10.3 \mu \mathrm{m}$ in length, base is $0.76-1.15 \mu \mathrm{m}$ in diameter, furcae diverge on $0.30-0.35 \mu \mathrm{m}$. Short spine scales are $1.3-3.2 \mu \mathrm{m}$ in length, base is $0.48-0.82 \mu \mathrm{m}$ in diameter, furcae diverge on $0.77-1.20 \mu \mathrm{m}$. Plate scales are $1.92-3.38 \times 1.26-1.92 \mu \mathrm{m}$.

Remarks: Spine scales are similar to A. nichollsi. Plate scales differ from $A$. nichollsi by lacking the radial slits and presence of numerous granules, medial thickening (0.49-0.58 $\mu \mathrm{m}$ in length) and dense margins. This species differs from A. polymorpha, A. siemensmae, A. valdiviense by the morphology of cup-shaped tips of short spine scales (Mikrjukov 2002). Morphology of observed scales corresponds to most known descriptions, except a different number of furcae in some papers: $2-3$ in Siemensma and Roijackers (1988a), Leonov and Plotnikov (2009), Plotnikov and Ermolenko (2015), Prokina and Mylnikov (2019); 7-8 in Leonov (2010a), Prokina et al. (2017c). Many authors noted a larger length of long spine scales - up to $15 \mu \mathrm{m}$ (Leonov and Plotnikov 2009, Leonov 2010a, Leonov and Mylnikov 2012, Plotnikov and Gerasimova 2017).

Distribution: Freshwaters of Europe (Siemensma and Roijackers 1988a, Mikrjukov 1993b), Africa (Prokina et al. 2017b), S. America (Prokina and Mylnikov 2019), Sri Lanka ([as A. pectinata ssp. ceylanica] Dürrschmidt 1987a). It was found in Russia in freshwaters of European part (Mikrjukov 1993a, Leonov and Plotnikov 2009, Leonov 2010a, Leonov and Mylnikov 2012, Plotnikov and Ermolenko 2015, Prokina et al. 2017c), in saline inland waters of Orenburg Region

Fig. 2. Morphology of observed scales of Acanthocystis genera (SEM): A-E - A. aff. amura (from plant debris and silt of Lake Chistoye), $\mathbf{F}-\mathbf{I}-A$. costata (from plant debris and silt of Lake Maklok), J-M - A. elenazhivotovae (from sand of Usman' River), $\mathbf{N}-\mathbf{Q}-A$. mikrjukovii (from peat of Sphagnum bog Klukvennoye-1). A, F, J, N - scales of the single cell; B-E, G-I, K-M, O-Q - spine and plate scales. Abbreviations: bs - base of spine scale; c.l.s - concave lateral side of plate scale; d.m - dense margin; fr - furca; gr - granules; hk - hooks; m.th - medial thickening; pl.sc - plate scale; r.r - radial ribs; r.s - radial slits; sh - shaft of spine scale; sp.sc - spine scale; th - tooth. Scale bars: A, F, J, N-10 $\mu \mathrm{m} ; \mathrm{B}, \mathrm{C}, \mathrm{E}, \mathrm{G}-\mathrm{I}, \mathrm{K}-\mathrm{M}, \mathrm{O}-\mathrm{Q}-1 \mu \mathrm{m} ; \mathrm{D}-0.5 \mu \mathrm{m}$. 
250 K. I. Prokina et al.

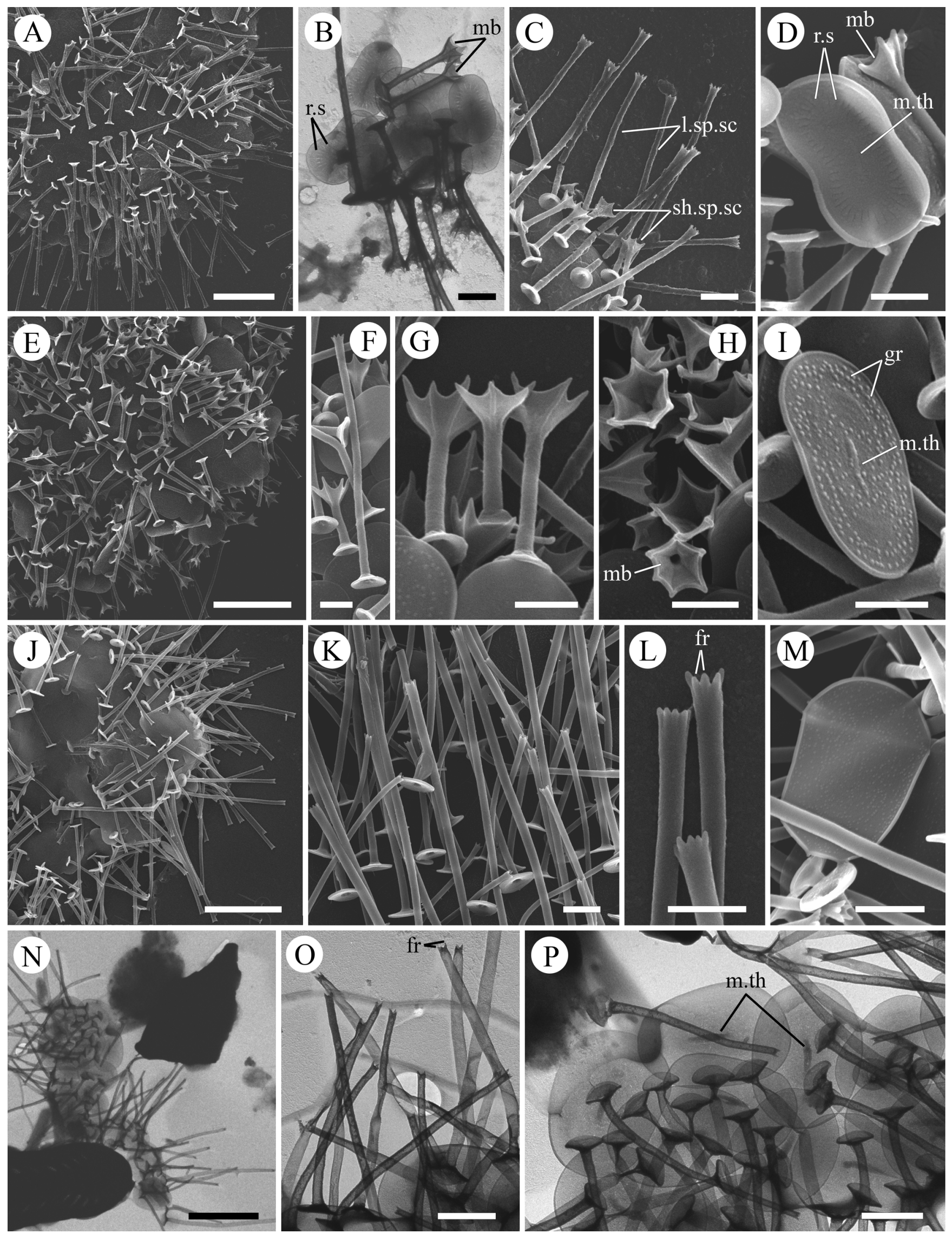


(Plotnikov and Ermolenko 2015, Plotnikov and Gerasimova 2017).

Acanthocystis penardi Wailes, 1925 [syn.: Acanthocystis spinifera Greef, 1869 sensu Penard, 1904; Acanthocystis heterospina Nicholls, 1983; Acanthocystis dresscheri Siemensma et Roijackers, 1988] (Fig. 3J-M)

Description: Spine scales consist of a hollow cylindrical shaft and circular base. Shaft is 3.84-17.29 $\mu \mathrm{m}$ in length, $0.25-0.41 \mu \mathrm{m}$ in diameter, base is $0.89-1.89 \mu \mathrm{m}$ in diameter. Tip of shaft divided on 4-7 furcae, diameter of the widened part is $0.33-0.62 \mu \mathrm{m}$. Plate scales are $2.71-4.75 \times 1.88-2.78 \mu \mathrm{m}$, with concave lateral sides, numerous granules and dense margins.

Remarks: Morphology of observed scales is similar to previous descriptions, but many authors noted up to 12 furcae on spine scales (Nicholls 1983; Mikrjukov 1993a, b; Leonov 2009; Leonov and Plotnikov 2009; Prokina et al. 2017b, c). Some authors have described the larger size of spine scales: length of the shaft up to $33 \mu \mathrm{m}$ (Mikrjukov 1993b, Leonov 2009), the diameter of the shaft up to $0.8 \mu \mathrm{m}$ (Mikrjukov 1993b), the diameter of base up to $3.3 \mu \mathrm{m}$ (Mikrjukov 1993b, Leonov 2009, Leonov and Plotnikov 2009). This species is similar to A. mylnikovi Leonov, 2010, A. taurica Mikrjukov, 1997, and A. dresscheri. A. mylnikovi differs by size and number of furcae as well as the presence of two type of spine scales. All spine scales of $A$. taurica are almost equal in length, 4 $\mu \mathrm{m}$ (Mikrjukov 2002). A. dresscheri differs by the presence of medial thickening on plate scales (Siemensma and Roijackers 1988a), however, K.A. Mikrjukov considers $A$. dresscheri a junior synonym of $A$. penardi (Mikrjukov 2002). Morphology of scales in A. penardi is also similar to A. spinosa (see below).

Distribution: Freshwaters of Europe (Mikrjukov 1993b), Asia (Kosolapova and Mylnikov 2015), Africa (Prokina et al. 2017b), N. America (Nicholls 1983), S. America (Dürrschmidt 1987a, Prokina and Mylnikov 2019), Malaysia (Dürrschmidt 1987a). It was found in Russia in freshwaters of European part (Mikrjukov 1993a, Leonov 2009, Leonov and Plotnikov 2009, Leonov and Mylnikov 2012, Prokina et al. 2017c).

Acanthocystis spinosa Cavalier-Smith et von der Heyden, 2007 (Fig. 3N-P)

Description: Spine scales consist of a hollow cylindrical shaft and circular base. Shaft is $2.88-8.14 \mu \mathrm{m}$ in length, $0.16-0.24 \mu \mathrm{m}$ in diameter, base is $0.59-0.68$ $\mu \mathrm{m}$ in diameter. Distal part of shaft slightly tapers up to $0.12-0.18 \mu \mathrm{m}$ in diameter and divided on $2-3$ short pointed furcae. Shafts of some spine scales are slightly curved in basal part, flattened and twisted. Oval plate scales are $2.19-3.17 \times 1.65-2.14 \mu \mathrm{m}$, with short medial thickening $(0.62-0.87 \mu \mathrm{m})$ and dense margins.

Remarks: Morphology of observed scales almost completely corresponds with the original description of this species from freshwaters of the UK (CavalierSmith and von der Heyden 2007), except the larger size of scales in the original description. Those authors noticed very large plate scales $(11-13 \mu \mathrm{m}$ in length - not typical for scales of Acanthocystis) as well as spine scales up to $17 \mu \mathrm{m}$ in the text. But on figures (Fig. 1a, p. 1187, and Fig. 4i-4k, p. 1193) they show different dimensions. Fig. 4k by Cavalier-Smith and von der Heyden (2007) shows length of plate scales about 12 $\mu \mathrm{m}$ (according to the scale bar), which corresponds to the description in the text. But in Fig. 4i we can calculate the length of plate scales as about $3.0-3.5 \mu \mathrm{m}$. Also, as we see in the photograph of a living cell (Fig. 1a), the length of plate scales cannot be $1 / 2$ of the diameter of the cell $(25 \mu \mathrm{m})$, otherwise they would be very clearly visible. Sizes of spine scales in Fig. $4 \mathrm{j}$ and $4 \mathrm{k}$ are four times different. The diameter of shaft of spine scales is about $0.8 \mu \mathrm{m}$, and diameter of base of spine scales is about 2.5-3.8 $\mu \mathrm{m}$ in Fig. 4k. But in Fig. $4 \mathrm{j}$ diameter of shaft of spine scales is about $0.2 \mu \mathrm{m}$, and diameter of base of spine scales is about $0.7 \mu \mathrm{m}$. Thus, we can assume that length of the scale bar on the fig. $4 \mathrm{k}$ is indicated incorrectly and there is a misprint in the text description. If so, sizes of observed scales completely correspond with the original description.

Fig. 3. Morphology of observed scales of Acanthocystis genera (A, C-M - SEM; B, N-P - TEM): A-D - A. nichollsi (A, C-D - from sand of Lake Maklok; B - from plant debris and silt of Lake Cherepashye), E-I - A. pectinata (from plant debris and silt of Usman' River), $\mathbf{J}-\mathbf{M}-$ A. penardi (from plant debris and silt of Lake Chistoye), N-P - A. spinosa (from Sphagnum of Sphagnum bog Klukvennoye-1). A, E, $\mathrm{J}, \mathrm{N}$ - scales of the single cell; B-D, F-I, K-M, O, P - spine and plate scales. Abbreviations: 1.sp.sc - long type of spine scales; mb - membrane; sh.sp.sc - short type of spine scales. Other abbreviations as in Fig. 2. Scale bars: A, E, J, N-10 $\mu$; B-D, F-I, K-M, O, P-1 $\mu$ m. 
252 K. I. Prokina et al.

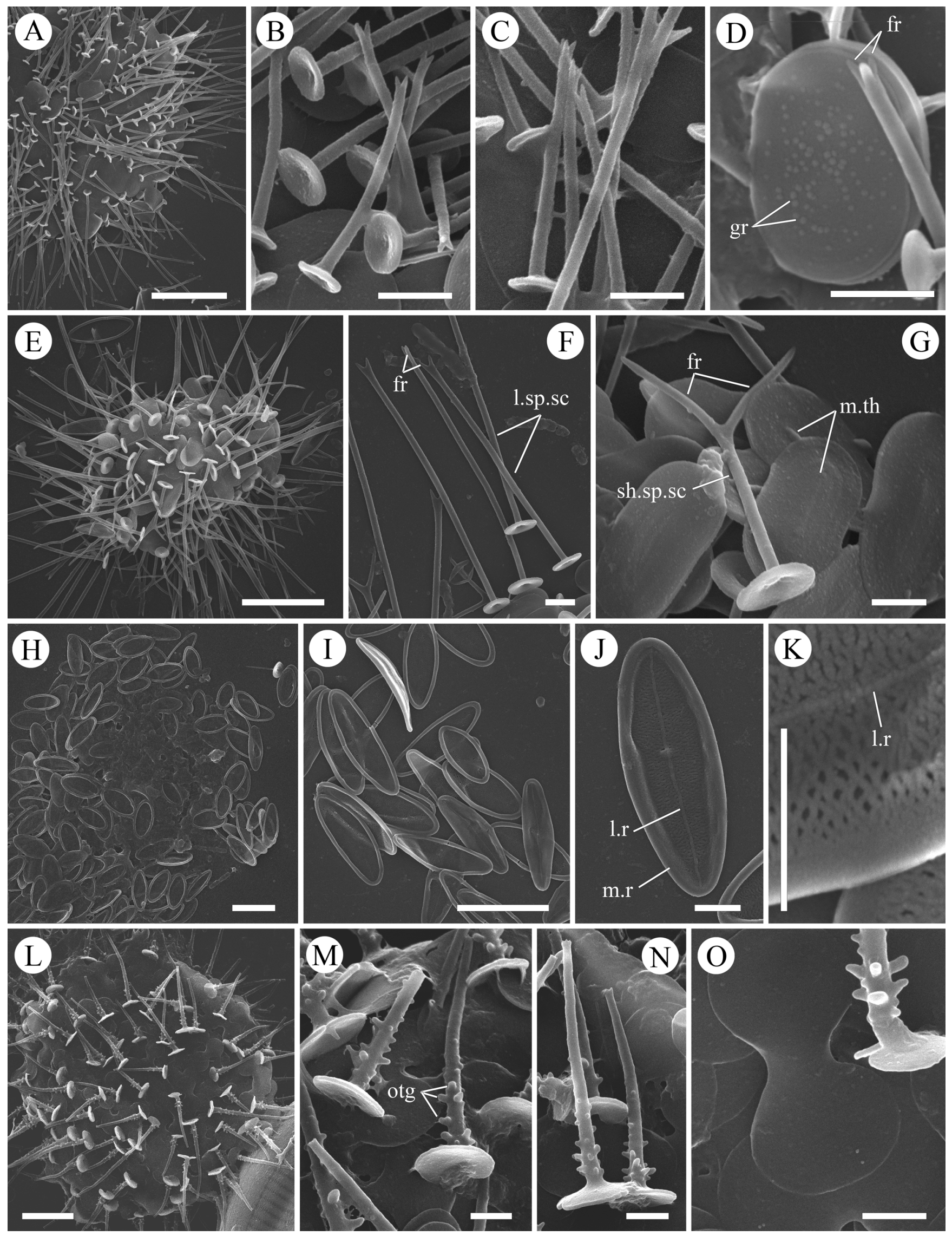


Spine scales with 2-3 furcae and slightly tapered distal end of the shaft occur in Acanthocystis spinifera sensu Siemensma et Roijackers, 1988. Plate scales of A. spinosa differ by larger oval plate scales without concave lateral sides and with medial thickening. Also, the shaft of spine scales in Acanthocystis spinifera sensu Siemensma et Roijackers, 1988 is located on the base eccentrically.

Acanthocystis trifurca Nicholls, 1983 [syn.: Acanthocystis myriospina Penard, 1890 sensu Dürrschmidt, 1985] (Fig. 4A-D)

Description: Spine scales consist of a hollow cylindrical shaft and circular base. Shaft is $2.25-11.52 \mu \mathrm{m}$ in length and $0.15-0.26 \mu \mathrm{m}$ in diameter, base is $0.56-1.08$ $\mu \mathrm{m}$ in diameter. Distal part of shaft divided on 3 pointed furcae $(0.12-0.23 \mu \mathrm{m}$ in length). Oval plate scales are 1.68-3.21 $\times 0.64-2.43 \mu \mathrm{m}$, with concave lateral sides, medial thickening $(0.55-1.34 \mu \mathrm{m}$ in length), numerous granules and dense margins.

Remarks: Morphology of observed scales is similar to previous descriptions. Some authors also observed pear-shaped plate scales (Leonov 2010a, Prokina et al. 2017c). Croome (1983) and Nicholls (1986) described smaller diameter of the shaft $(0.10-0.15 \mu \mathrm{m})$. Many researchers noted smooth plate scales without granules.

Distribution: Freshwaters of N. America (Nicholls 1983), S. America (Dürrschmidt 1985), Australia (Croome 1986), Crimean Peninsula (Mikrjukov 1999). It was found in Russia in freshwaters of European part (Leonov and Plotnikov 2009, Leonov 2010a, Plotnikov and Ermolenko 2015, Prokina et al. 2017c), in saline inland waters of Orenburg Region (Plotnikov and Gerasimova 2017), in the Black Sea (Leonov 2010a).

Acanthocystis turfacea Carter, 1863 (Figs 1C, $4 \mathrm{E}-\mathrm{G})$

Description: Diameter of protoplast of living cell is $29 \mu \mathrm{m}$. Two types of spine scales, both consist of a hollow cylindrical shaft and circular base, distal part of shaft divided into 2 furcae, without membrane between tips of furcae. Long spine scales: shaft is 13.06-16.50 $\mu \mathrm{m}$ in length, $0.35-0.44 \mu \mathrm{m}$ in diameter, base is 2.06 $2.43 \mu \mathrm{m}$ in diameter; furcae pointed, $0.53-0.89 \mu \mathrm{m}$ in length, distance between tips of furcae $-0.59-0.82 \mu \mathrm{m}$. Short spine scales: shaft is $6.21-8.85 \mu \mathrm{m}$ in length, $0.35-0.40 \mu \mathrm{m}$ in diameter, base is $1.74-2.09 \mu \mathrm{m}$ in diameter; long furcae $(2.71-3.69 \mu \mathrm{m})$ slightly tapers to round tips, distance between tips of furcae $3.22-5.27$ $\mu \mathrm{m}$. Oval plate scales are 3.74-4.50×1.98-2.54 $\mu \mathrm{m}$, with large rare granules, medial thickening (1.46$2.33 \times 0.22-0.23 \mu \mathrm{m})$ and dense margins.

Remarks: Morphology of observed scales corresponds to previous descriptions. Some authors noted smaller spine scales of both type: length of shaft - 1.8 $11.5 \mu \mathrm{m}$, diameter of base - 0.37-1.6 $\mu \mathrm{m}$ (Dürrschmidt 1985, Croome et al. 1987, Leonov and Plotnikov 2009, Plotnikov and Ermolenko 2015, Plotnikov and Gerasimova 2017), as well as larger length of shaft - up to 65 $\mu \mathrm{m}$, diameter of shaft - up to $0.7 \mu \mathrm{m}$ (Nicholls 1983, Croome 1986, Prokina et al. 2017c).

Distribution: Freshwaters of Asia (Biyu 2000, Charubhun and Charubhun 2000, Takamura et al. 2000), N. America (Nicholls 1983), S. America (Dürrschmidt 1985), Australia (Croome 1986); marine waters of Europe (Vørs 1992, Mikrjukov 1999, Leonov 2010a), Antarctica (Croome et al. 1987). It was found in Russia in freshwaters of European part (Mikrjukov 1993a, Leonov and Plotnikov 2009, Leonov 2010a, Plotnikov and Ermolenko 2015, Prokina et al. 2017c), in saline inland waters of Orenburg and Volgograd Regions (Gerasimova and Plotnikov 2015, Plotnikov and Gerasimova 2017).

*****aphidocystidae Zlatogursky in Zlatogursky et al., 2018

Raphidocystis symmetrica (Penard, 1904) Zlatogursky in Zlatogursky et al., 2018 [bas.: Raphidiophrys symmetrica Penard, 1904; syn.: Polyplacocystis symmetrica (Penard, 1904) Mikrjukov, 1996] (Figs 1D, $4 \mathrm{H}-\mathrm{K})$

Description: Oval plate scales are 6.02-8.68×2.06$3.09 \mu \mathrm{m}$. Length to width ratio is $1.85-3.41$. Dense marginal rim is $0.21-0.34 \mu \mathrm{m}$ in diameter. Inner space of

Fig. 4. Morphology of observed scales of Acanthocystis, Raphidocystis and Choanocystis genera (SEM): A-D - A. trifurca (from plant debris and silt of Lake Krugloye); $\mathbf{E}-\mathbf{G}-$ A. turfacea (from plant debris and silt of Lake Chistoye); $\mathbf{H}-\mathbf{K}-$ R. symmetrica (from plant debris and silt of Lake Chistoye); L-O - Ch. aculeata (from sand of Lake Maklok). A, E, H, L - scales of the single cell; B-D, F, G, I-K, M-O spine and plate scales. Abbreviations: 1.r - longitudinal rib; m.r - marginal rim; otg - outgrows. Other abbreviations as in Figs 2, 3. Scale bars: A, E, H, L- $10 \mu \mathrm{m}$; B-D, F, G, I-K, M-O - $1 \mu \mathrm{m}$. 
254 K. I. Prokina et al.

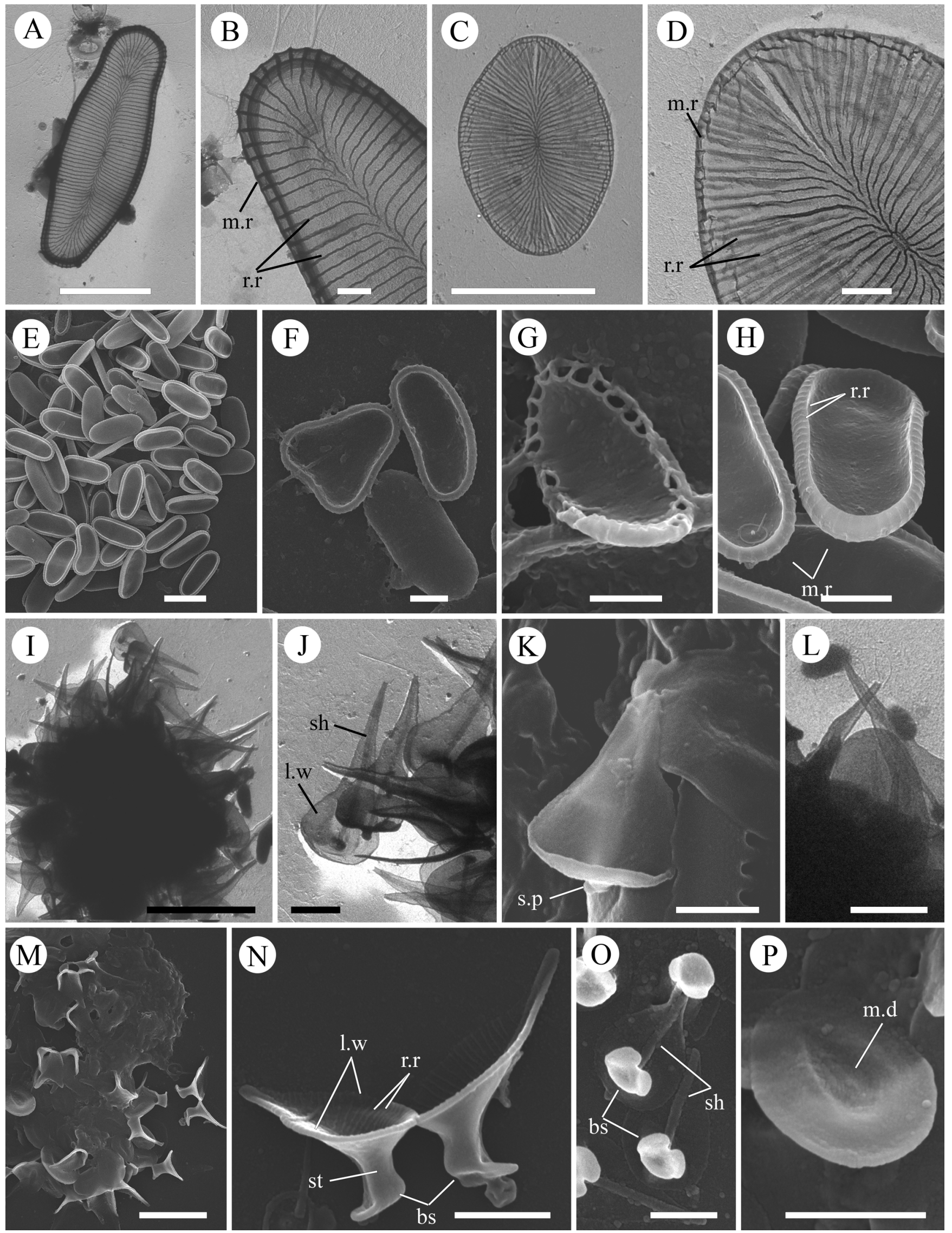


scale with reticular texture (Fig. 4K). Longitudinal rib $(0.08-0.14 \mu \mathrm{m}$ in length) divided scale into two halves.

Remarks: Scales of this species are similar to plate scales of $R$. ambigua and $R$. tubifera. R. ambigua differs by the presence of narrowed elongate types of plate scales; $R$. tubifera differs by the presence of funnelshaped spine scales.

Distribution: Freshwaters of Europe (Siemensma and Roijackers 1988b), N. America (Nicholls and Dürrschmidt 1985), Greenland (Ikävalko et al. 1996). It was found in Russia in freshwaters of Voronezh Region (Leonov and 2010a).

****Pterocystida Cavalier-Smith et von der Heyden, 2007 emend. Shishkin et Zlatogursky, 2018

****Raphidista Shishkin et Zlatogursky, 2018

$* * * * *$ Choanocystidae Cavalier-Smith et von der Heyden, 2007

Choanocystis aculeata (Hertwig et Lesser, 1874) Siemensma et Roijackers, 1988 [bas.: Acanthocystis aculeata Hertwig et Lesser, 1874; syn.: A. serrata Nicholls, 1983] (Figs 1E, 4L-O)

Description: Diameter of protoplast of living cells is $38-40 \mu \mathrm{m}$. Spine scales consist of a hollow cylindrical shaft, which asymmetrically sitting on circular flattened base. Shaft is $4.92-13.72 \mu \mathrm{m}$ in length, diameter of proximal part is $0.47-0.63 \mu \mathrm{m}$, diameter of distal part is $0.25-0.29 \mu \mathrm{m}$. Proximal part $(1 / 3$ of the entire length) with round finger-like outgrowths (0.11-0.45 $\mu \mathrm{m}$ in length, $0.05-0.39 \mu \mathrm{m}$ in diameter). Tip divided on 4-7 teeth. Base is 1.69-2.47 $\mu \mathrm{m}$ in diameter, with a small excavation. Dumbbell-shaped plate scales are 4.36-5.47 $\mu \mathrm{m}$ in length, width of expanded part is 2.57-3.05 $\mu \mathrm{m}$, width of narrowed central part is 0.88 $1.73 \mu \mathrm{m}$.

Remarks: Observations of the scales are in the agreement with previous descriptions. Some authors observed additionally very long plate scales (up to 12.9 $\mu \mathrm{m}$ ) (Dürrschmidt 1985, Siemensma and Roijackers 1988a). Nicholls (1983) described longer outgrowths (up to $0.7 \mu \mathrm{m}$ ); Croome (1986) observed the absence of outgrowths on spine scales of some cells.

Distribution: Freshwaters of Europe (Siemensma and Roijackers 1988a, Mikrjukov 1993b), Asia (Wujek and Saha 2006), N. America ([as A. serrata] Nicholls 1983, Wujek 2003), S. America (Dürrschmidt 1985), Australia (Croome 1986), fresh and marine waters of Crimea (Mikrjukov 1999). It was found in Russia in freshwaters of European part (Mikrjukov 1993a).

*****Raphidiophryidae Febvre-Chevalier et Febvre, 1984 emend. Shishkin et Zlatogursky, 2018

Raphidiophrys capitata Siemensma et Roijackers, 1988 [syn.: Raphidiophrys elegans sensu Nicholls et Dürrschmidt, 1985] (Figs 1F, 5A-B)

Description: Diameter of protoplast of living cells is $48-54 \mu \mathrm{m}$. Elongate oval plate scales are 8.36$12.24 \times 3.38-4.32 \mu \mathrm{m}$, with narrowing elongated ends. Length to width ratio is 2.05-4.02. Edges of scales are bent inside and form marginal rim $0.25-0.37 \mu \mathrm{m}$ in diameter. Radial ribs with variable length extend from edges to the center. Distances between ribs on marginal rim are $0.16-0.30 \mu \mathrm{m}$.

Remarks: Morphology of observed scales corresponds to previous descriptions, except larger length to width ratio (3.0-5.4) in the original description (Siemensma and Roijackers 1988b).

Distribution: Freshwaters of Europe (Siemensma and Roijackers 1988b), N. and S. America ([as R. elegans] Nicholls and Dürrschmidt 1985, Wujek 2003). These are the first observations in Russia.

Raphidiophrys intermedia Penard, 1904 (Fig. $5 \mathrm{E}-\mathrm{H})$

Description: Oval, rare triangular plate scales are $4.54-10.0 \times 2.22-5.0 \mu \mathrm{m}$. Length to width ratio is 1.94 3.84. Edges of scales are bent inside and form marginal rim $0.36-0.63 \mu \mathrm{m}$ in diameter. Radial ribs extend from edges to the center, visible on the outer surface of the scales. Distances between ribs on marginal rim are $0.26-0.43 \mu \mathrm{m}$.

Fig. 5. Morphology of observed scales of Raphidiophrys and Pterocystis genera (A-D, I-L - TEM; E-H, M-P - SEM): A-B - R. capitata (from sand of Lake Maklok); C-D - R. ovalis (from Sphagnum of Sphagnum bog Klukvennoye-1); $\mathbf{E}-\mathbf{H}-R$. intermedia (from plant debris and silt of Lake Maklok); I-L - P. foliacea (from sand of Usman' River); M-P - P. pulchra (from plant debris and silt Lake Chistoye). E, I, $\mathrm{M}$ - scales of the single cell; A, B, C, D, F-H, J-L, N-P - spine and plate scales. Abbreviations: 1.w - lateral wing; m.d - medial depression of plate scale; s.p - subapical protrusion; st - stalk. Other abbreviations as in Figs 2, 4. Scale bars: E, I - $10 \mu \mathrm{m} ; \mathrm{A}, \mathrm{C}-5 \mu \mathrm{m}$; M - $3 \mu \mathrm{m}$; $\mathrm{B}, \mathrm{D}, \mathrm{F}-\mathrm{H}, \mathrm{J}-\mathrm{L}, \mathrm{N}-\mathrm{P}-1 \mu \mathrm{m}$. 

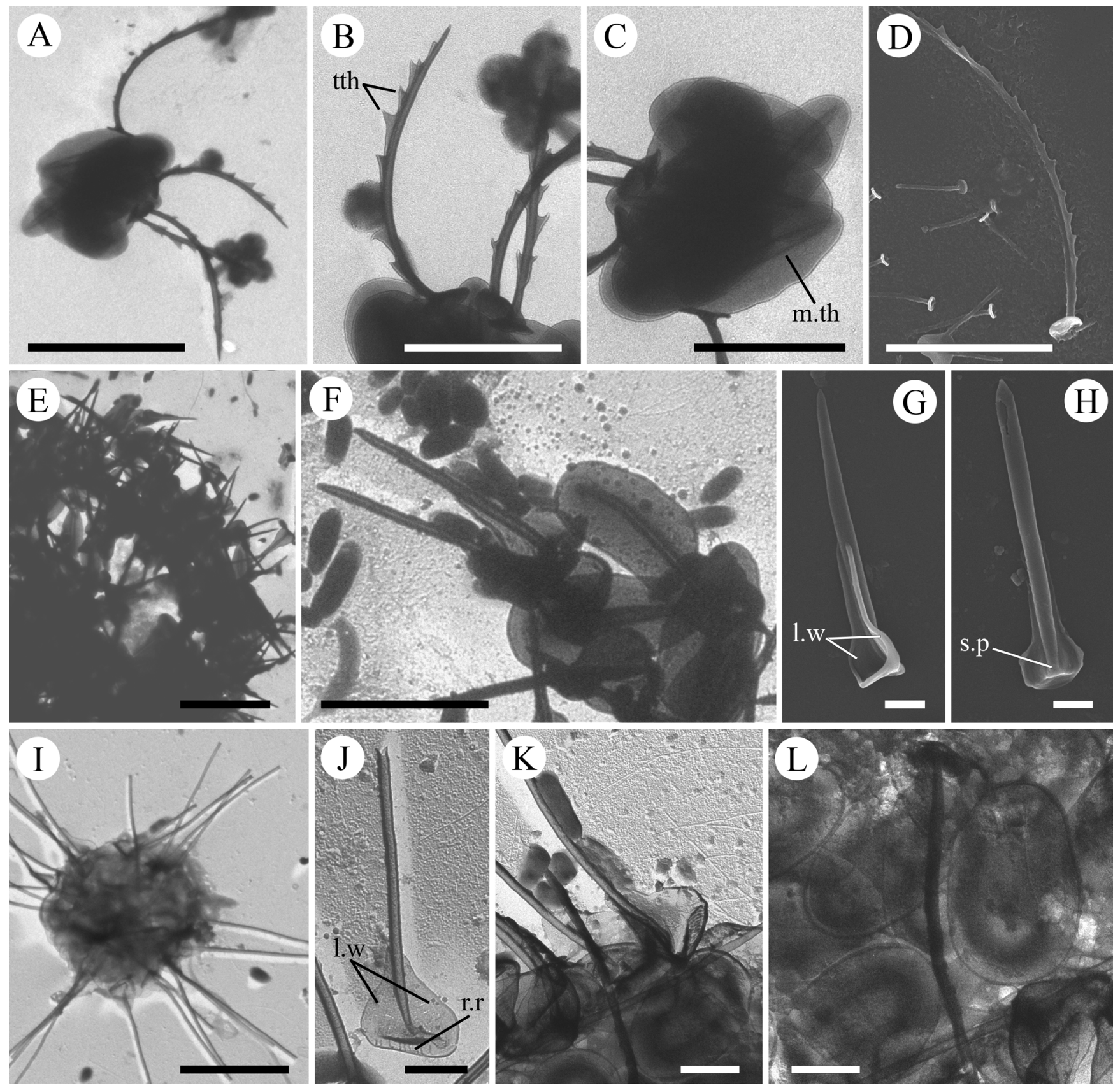

Fig. 6. Morphology of observed scales of Raineriophrys genera (A-C, E, F, I-L - TEM; D, G, H - SEM): A-D - R. echinata (A-C - from peat of Sphagnum bog Klukvennoye-2; D - from Sphagnum of Sphagnum bog Klukvennoye-3), E-H - R. erinaceoides (E, F - from water column of Lake Vosmerka; G, H - from plant debris and silt of Lake Cherepashye), I-L - R. fortesca (I - Vosmerka, J-L - Cherepashye). E, I- scales of the single cell; A-D, F-H, J-L - spine and plate scales. Abbreviations as in Fig. 2, 5. Scale bars: A, E, I - $10 \mu \mathrm{m}$; B-D, F - 5 $\mu \mathrm{m} ; \mathrm{G}, \mathrm{H}, \mathrm{J}-\mathrm{L}-1 \mu \mathrm{m}$.

Distribution: Freshwaters of USA (Wujek 2005), Australia (Croome 1987), Canada, Chile, New Zealand (Nicholls and Dürrschmidt 1985), Sweden, Netherlands (Siemensma and Roijackers 1988b). It was found in Rus- sia in freshwaters of European part (Leonov 2009, 2010a; Leonov and Mylnikov 2012; Prokina et al. 2017c).

Raphidiophrys ovalis (Dürrschmidt in Nicholls et Dürrschmidt, 1985) Siemensma et Roijackers, 

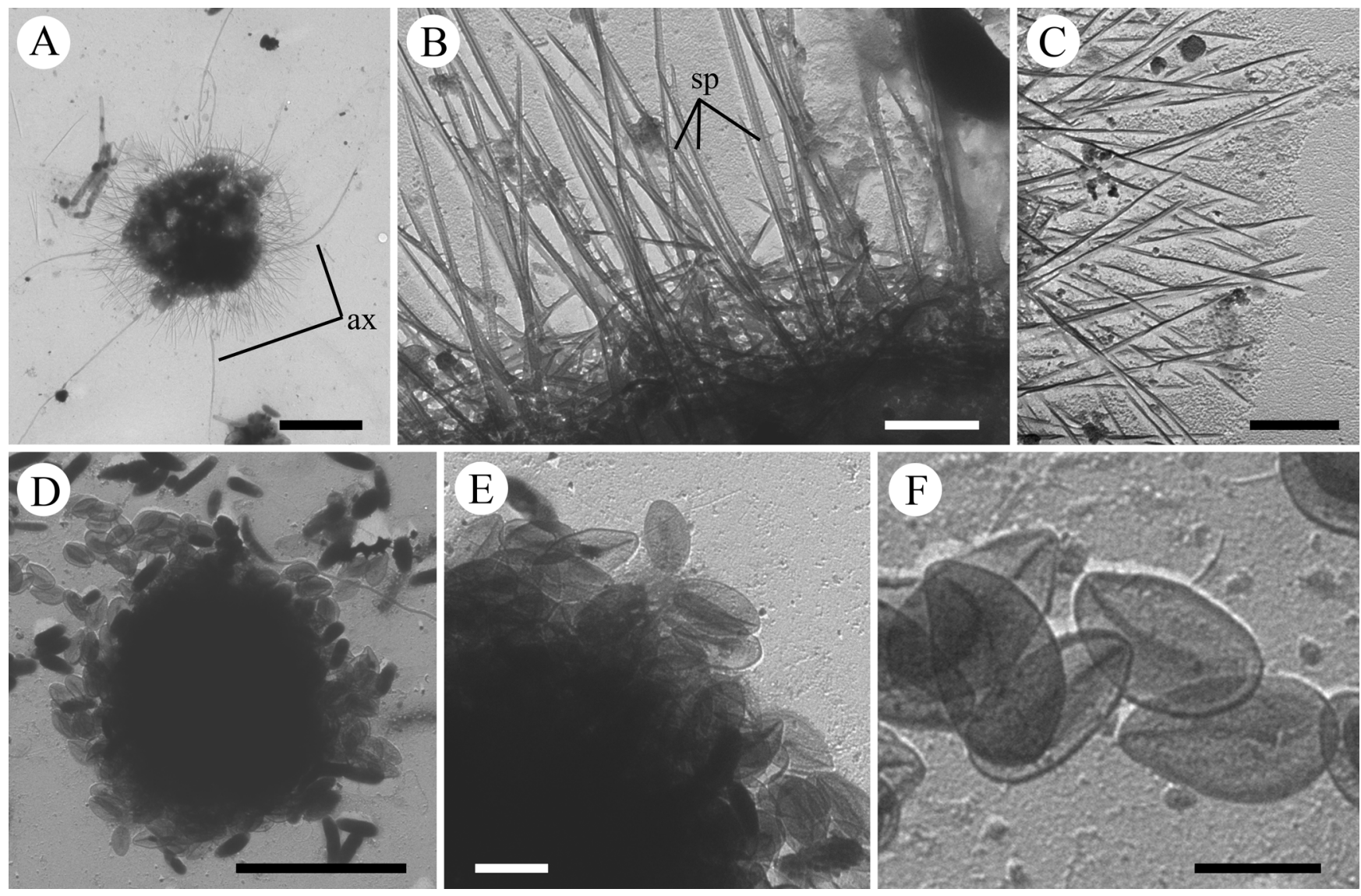

Fig. 7. Morphology of observed scales of unidentified species (TEM): A-C - Heterophrys-like organism (A - from plant debris and silt of Usman' River; B, C - from plant debris and silt of Lake Krugloye; A - whole cell; B, C - spicules), D-F - unidentified Centrohelea sp. (from water column of Lake Vosmerka; D - scales of the single cell; E, F - plate scales). Abbreviations: sp - spicules. Other abbreviation as in Fig. 1. Scale bars: A, D - $10 \mu \mathrm{m} ; \mathrm{B}, \mathrm{C}, \mathrm{E}, \mathrm{F}-1 \mu \mathrm{m}$.

1988 [bas.: Raphidiophrys orbicularis ssp. ovalis Dürrschmidt in Nicholls et Dürrschmidt, 1985; syn.: Raphidiophrys intermedia sensu Siemensma, 1981] (Fig. 5C-D)

Description: Oval plate scales are $7.21 \times 5.14 \mu \mathrm{m}$, with slightly narrowing elongated ends. Length to width ratio is 1.4 . Dense marginal rim is $0.12-0.15 \mu \mathrm{m}$ in diameter. Radial ribs extend from edges to the center, visible on the outer surface of the scales. Distances between ribs on marginal rim are $0.11-0.20 \mu \mathrm{m}$.

Remarks: Morphology of observed scale corresponds to previous descriptions, except the smaller size of scales, observed by Nicholls and Dürrschmidt (1985): $2.0-6.3 \times 2.2-4.8 \mu \mathrm{m}$.

Distribution: Freshwaters of Europe (Siemensma and Roijackers 1988b), N. America (Wujek 2005), Chile, New Zealand, Japan ([as $R$. orbicularis ssp. ovalis] Nicholls and Dürrschmidt 1985). It was found in Russia in freshwaters of Voronezh Region (Leonov 2010a).

****Pterista Shishkin et Zlatogursky, 2018

*****Pterocystidae Cavalier-Smith et von der Hey-

den, 2007

Pterocystis foliacea (Dürrschmidt, 1985) Siemensma, 1991 [bas.: Acanthocystis foliacea Dürrschmidt, 1985] (Fig. 5I-L)

Description: Spine scales leaf-shaped, consist of a hollow cylindrical shaft, lateral and basal wings. Wings connect to each other perpendicularly, forming subapical protrusion. Shaft is $2.49-6.02 \mu \mathrm{m}$ in length, $0.15-0.20 \mu \mathrm{m}$ in diameter. Lateral wings are $2.11-$ $2.58 \mu \mathrm{m}$ in width, slightly narrowed to truncated tips $(0.24-0.46 \mu \mathrm{m}$ in width). Oval plate scales are 3.67$4.39 \times 1.92-2.63 \mu \mathrm{m}$, with medial thickening and dense margins. 


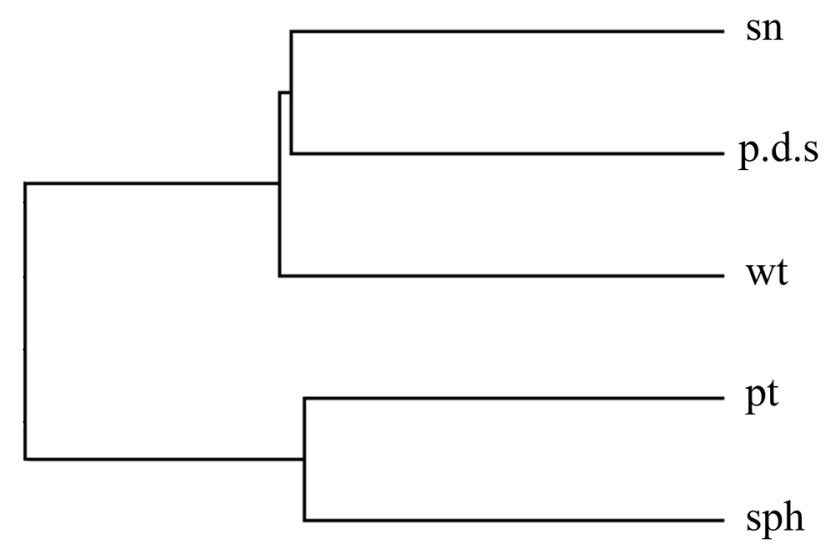

$\begin{array}{lllllllllll}0 & 10 & 20 & 30 & 40 & 50 & 60 & 70 & 80 & 90 & 100\end{array}$

Fig. 8. Dendrogram showing the Bray-Curtis similarity (\%) of studied microbiotopes by species diversity of centrohelids. Abbreviations: p.d.s - plant debris and silt; pt - peat from mire's lakes; sn - sand; sph - Sphagnum from hollows; wt - water column.

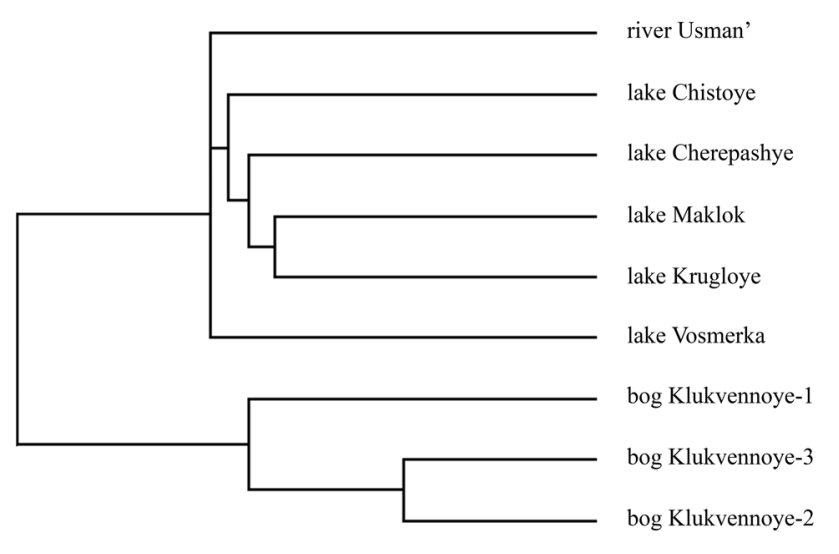

$\begin{array}{llllllllll}10 & 20 & 30 & 40 & 50 & 60 & 70 & 80 & 90 & 100\end{array}$

Fig. 9. Dendrogram showing the Bray-Curtis similarity (\%) of studied water bodies by species diversity of centrohelids.

Remarks: Morphology of observed scales corresponds to previous descriptions, however, many authors described smaller plate scales $(2.5-3.1 \times 1.4-2.0 \mu \mathrm{m})$ (Dürrschmidt 1985, 1987b; Gaponova 2008; Plotnikov and Gerasimova, 2017; Prokina and Mylnikov 2019).

Distribution: Freshwaters of Europe (Gaponova 2008), Asia (Wujek and Saha 2006), Australia (Croome 1987), Africa (Wujek and Ogundipe 2002), S. America (Dürrschmidt 1985, 1987b; Prokina and Mylnikov 2019), Japan, New Zealand, Sri Lanka (Dürrschmidt 1987b). It was found in Russia in freshwaters of Orenburg Region (Ermolenko and Plotnikov 2013), in saline inland waters of Volgograd Region (Plotnikov and Gerasimova 2017), in the Black Sea (unpubl. data).

Pterocystis pulchra (Dürrschmidt, 1985) Siemensma, 1991 [bas.: Acanthocystis pulchra Dürrschmidt, 1985] (Fig. 5M-P)

Description: Spine scales with a complex structure: hollow curved shaft (1.71-3.14 $\mu \mathrm{m}$ in length, 0.16-0.20 $\mu \mathrm{m}$ in diameter) is located on heart-shaped flattened base plate $(0.56-0.89 \mu \mathrm{m}$ in diameter). Lateral wings connected to each other in basal part, forming a hollow broad stalk (0.48-0.71 $\mu \mathrm{m}$ in diameter). Lateral wings expand into a funnel-shaped structure (diameter of the widened part is $1.32-1.75 \mu \mathrm{m}$ ) in a middle part. Distal part of wings conically tapered, forming a pointed tip. Inner side of wings with radial ribs extended from shaft to margins, and from basal part of the funnel to the base. Oval or ovoid plate scales are $1.32-2.25 \times 0.89-1.33 \mu \mathrm{m}$, with medial depression $(0.62-1.03 \times 0.18-0.41 \mu \mathrm{m})$.

Remarks: Morphology of observed scales corresponds to previous descriptions, except Dürrschmidt (1985) noted larger size of plate scales $(3.0-3.3 \times 1.7-$ $2.0 \mu \mathrm{m})$ and spine scales $(3.0-4.0 \times 3.1-3.8 \mu \mathrm{m})$. Spine scales of this species differ from spine scales of $P$. plumosa by not extending beyond the lateral wings shaft.

Distribution: Freshwaters of USA (Wujek 2005), Chile, New Zealand (Dürrschmidt 1985, 1987b). This is the first record in Russia.

Raineriophrys echinata (Rainer, 1968) Mikrjukov, 2001 [bas.: Acanthocystis echinata Rainer, 1968; syn.: Echinocystis echinata (Rainer, 1968) Mikrjukov, 1997; Pterocystis echinata (Rainer, 1968) Siemensma et Roijackers, 1988] (Fig. 6A-D)

Description: Spine scales consist of a hollow curved shaft, asymmetrically sitting on a circular flattened base. Shaft is 9.19-23.66 $\mu \mathrm{m}$ in length, 0.29-0.60 $\mu \mathrm{m}$ in diameter, base is $1.19-1.92 \mu \mathrm{m}$ in diameter. Narrow lateral wings $(0.11-0.56 \mu \mathrm{m}$ in width) with pointed teeth. Oval plate scales are $4.95-5.18 \times 2.11-2.43 \mu \mathrm{m}$, with medial thickening almost equal the length of scale, $0.35-0.42 \mu \mathrm{m}$ in diameter.

Remarks: Morphology of observed scales corresponds to previous descriptions, however, many authors noted larger size of plate scales $(4.7-8.0 \times 2.2-3.4$ $\mu \mathrm{m})$ (Siemensma and Roijackers 1988a; Leonov 2009, 2010a; Leonov and Plotnikov 2009; Leonov and Mylnikov 2012). 
Distribution: Freshwaters of Europe (Siemensma and Roijackers 1988a). It was found in Russia in freshwaters of European part (Leonov 2009, 2010a; Leonov and Plotnikov 2009; Leonov and Mylnikov 2012; Prokina et al. 2017c).

Raineriohrys erinaceoides (Petersen et Hansen, 1960) Mikrjukov, 2001 [bas.: Acanthocystis erinaceoides Petersen et Hansen, 1960; syn.: Echinocystis erinaceoides (Petersen et Hansen, 1960) Mikrjukov, 1997; Pterocystis erinaceoides (Petersen et Hansen, 1960) Siemensma, 1991; Raineria erinaceoides (Petersen et Hansen, 1960) Mikrjukov, 1999] (Fig. 6E-H)

Description: Spine scales consist of a hollow cylindrical shaft, lateral and basal wings. Shaft is 5.02$8.75 \mu \mathrm{m}$ in length, $0.29-0.46 \mu \mathrm{m}$ in diameter, conically tapers to pointed tip. Lateral wings are 2.53-5.22 $\mu \mathrm{m}$ in length, narrow from the base to distal end. Basal part of lateral wings connected to basal wing, forming subapical protrusion (1.41-2.26 $\mu \mathrm{m}$ in diameter). Oval plate scales are $4.71-5.24 \times 2.27-2.81 \mu \mathrm{m}$, with medial thickening $(3.06-3.77 \times 0.26-0.44 \mu \mathrm{m})$ and dense margins.

Distribution: Freshwaters of Europe (Mikrjukov 1993b, Gaponova 2008), Asia (Kosolapova and Mylnikov 2015), Africa (Wujek and Ogundipe 2002), N. America (Nicholls 1983, Wujek 2006), S. America (Dürrschmidt 1985, 1987b; Prokina and Mylnikov 2019), Australia (Croome 1986), Sri Lanka (Dürrschmidt 1987b), Crimean Penninsula (Mikrjukov 1999); marine waters of Europe (Vørs 1992, Mikrjukov 2001). It was found in Russia in freshwaters of European part (Mikrjukov 1993a, Leonov 2010a, Leonov and Plotnikov 2009, Ermolenko and Plotnikov 2013, Plotnikov and Ermolenko 2015), in saline inland waters of Orenburg Region (Plotnikov and Gerasimova 2017).

Raineriophrys fortesca (Nicholls, 1983) Mikrjukov, 1999 [bas.: Acanthocystis fortesca Nicholls, 1983; syn.: Acanthocystis pantopodeoides Nicholls, 1983; Acanthocystis cuneiformis Dürrschmidt, 1985; Pterocystis fortesca (Nicholls, 1983) Siemensma et Roijackers, 1988] (Fig. 6I-L)

Description: Spine scales consist of a hollow cylindrical shaft, lateral and basal wings. Shaft is 4.73$11.06 \mu \mathrm{m}$ in length, $0.18-0.27 \mu \mathrm{m}$ in diameter, distal end divided on 2-5 teeth. Lateral wings are 1.80-2.64 $\mu \mathrm{m}$ in length, $1.57-2.02 \mu \mathrm{m}$ in diameter, proximal part connected to basal wings, forming subapical protrusion, triangular in outline. Margins of wings bend out- wards. Inner side of basal wing with radial ribs. Oval plate scales are $2.75-2.88 \times 1.76-1.88 \mu \mathrm{m}$, darkened by protoplast.

Remarks: Morphology of observed scales corresponds to previous descriptions, however, some authors noted larger length of spine scales (13-24 $\mu \mathrm{m})$ (Nicholls 1983, Dürrschmidt 1985, Mikrjukov 1993a) and smaller size of plate scales $(1.6-2.9 \times 1.0-1.9 \mu \mathrm{m})$ (Mikrjukov 1993a, Plotnikov and Ermolenko 2015).

Distribution: Freshwaters of Europe (Siemensma and Roijackers 1988a), N. America ([as A. fortesca and A. pantopodeoides] Nicholls 1983, Wujek 2003, 2005), S. America ([as A. cuneiformis] Dürrschmidt 1985), Australia ([as A. pantopodeoides] Croome 1986); marine waters of Europe (Vørs 1992). It was found in Russia in freshwaters of European part (Mikrjukov 1993a, Plotnikov and Ermolenko 2015), White Sea (Leonov 2010a).

\section{Unidentified species}

Heterophrys-like organism (Fig. 7A-C)

Description: Organic spindle-shaped spicules are 2.75-7.57 $\mu \mathrm{m}$ in length, $0.05-0.09 \mu \mathrm{m}$ in width. Spicules are slightly flattened and twisted along longitudinal axis, ends taper to pointed tips. Basal part of spicules submerged into mucopolysaccharide capsule, few axopodia are visible (Fig. 7A).

Remarks: Organisms with organic spindle-shaped spicules were previously found in both fresh and marine waters and identified as species of Heterophrys, Marophrys, and Sphaerastrum (Mikrjukov 2002, Cavalier-Smith and von der Heyden 2007). However, recent studies have revealed a close similarity between spicule-bearing Heterophrys-like organisms and scalebearing species by both molecular (18S rDNA sequences of Polyplacocystis species is similar to sequence of Heterophrys-like organism) and morphological data (presence of intermediate forms possessing characteristic Raphidiophrys glabra plate scales and spicules at the same time) (Zlatogursky 2016, Zlatogursky et al. 2018). Based on these observations, Zlatogursky with coauthors (Zlatogursky et al. 2018) have suggested dimorphism of the life cycle in centrohelids with the presence of scales-bearing and spicules-bearing stages. So, Heterophrys-like organism can be a stage of the life cycle of some other centrohelid species.

Unindentified Centrohelea sp. (Fig. 7D-F)

Description: Oval-ovoid plate scales are 1.28$1.87 \times 0.92-1.03 \mu \mathrm{m}$, with dense margins. Medial thick- 
ening (0.97-1.22 $\mu \mathrm{m}$ in length) extends from more narrowed pole to broadened one. Another type of scales was not observed.

Remarks: Observed plate scales may belong to several species of centrohelids, but the second type of plate or spine scales was not found.

\section{DISCUSSION}

A total of 20 species of centrohelid heliozoans as well as a Heterophrys-like organism and one unidentified Centrohelea species were found. Three species are new records for Russia: Acanthocystis spinosa, Raphidiophrys capitata, and Pterocystis pulchra. Eight species are new records for the Middle Russian forest steppe: Acanthocystis costata, A. elenazhivotovae, A. spinosa, Raphidiophrys capitata, Pterocystis foliacea, P. pulchra, Raineriophrys fortesca, and Choanocystis aculeata. These new records are most likely caused by insufficient sampling in the studied territory and potentially indicate a large species diversity of centrohelids in the region. The largest number of observed species belong to families Acanthocystidae (Acanthocystis - 10 species), and Pterocystidae (Raineriophrys - 3 species, Pterocystis - 2 species). Families Raphidiophryidae (Raphidiophrys - 3 species), Raphidocystidae (Raphidocystis - 1 species), and Choanocystidae (Choanocystis -1 species) were characterized by the lowest species richness. The most common species observed in the three water bodies were Acanthocystis nichollsi, Raphidiophrys capitata, and the Heterophrys-like organism. Furthermore, fourteen species (Acanthocystis aff. amura, A. costata, A. elenazhivotovae, A. pectinata, A. penardi, A. spinosa, A. turfacea, Raphidiophrys intermedia, R. ovalis, Raphidocystis symmetrica, Pterocystis foliacea, P. pulchra, Choanocystis aculeata, and Unidentified Centrohelea sp.) were found only once.

Morphology of the observed scales mainly corresponds to previous descriptions, but some deviations in the morphology and size of the scales were present. Many species are very common and often occur all over the globe (Acanthocystis nichollsi, A. pectinata, A. penardi, A. trifurca, A. turfacea, Raphidiophrys capitata, Pterocystis foliacea, P. pulchra, Raineriophrys erinaceoides, $R$. fortesca, and Choanocystis aculeata). They are well studied and their taxonomic diagnoses are sufficiently refined.

Five species (Acanthocystis aff. amura, A. costata, A. elenazhivotovae, A. mikrjukovii, A. spinosa) were recorded for the first time after their original description and can be extremely rare organisms. On the other hand, all these species were described recently (Cavalier-Smith and von der Heyden 2007, Leonov 2010b, Zlatogursky 2015, Zlatogursky et al. 2017), and we can expect that their number of records will increase in the future. It should be noted that one species (Acanthocystis mikrjukovii) was found in the type locality - bog Klukvennoye-1 (Leonov 2010b).

Two heliozoans were not identified. Heterophryslike organisms can be an unknown stage of the life cycle of some centrohelids, so we can't consider this protist as a single species or new species of heliozoans with confidence. Scales of Centrohelea sp. were represented by only one type of plate scale, which is not typical for centrohelids. Therefore, the morphology of these plate scales is quite typical for the inner layer of scales in many species. The heap assemblage of scales clearly indicates that they all belong to one cell. These observations may be useful for future taxonomic research.

Analysis of the species distribution within microbiotopes has shown that the highest species diversity (14 species) was recorded in plant debris and silt (Acanthocystis aff. amura, A. costata, A. nichollsi, A. pectinata, A. penardi, A. trifurca, A. turfacea, Raphidiophrys

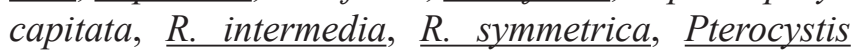
pulchra, Raineriophrys erinaceoides, $\underline{R}$. fortesca, and Heterophrys-like organism). Nine of them (underlined) were observed only in this type of microbiotope. Seven species (Acanthocystis elenazhivotovae, A. nichollsi, A. trifurca, Raphidiophrys capitata, Pterocystis foliacea, Choanocystis aculeata, Heterophrys-like organism) were found in sand, and three of them (underlined) were unique to the sand biotope. Four species (Acanthocystis trifurca, Raineriophrys erinaceoides, Heterophrys-like organism, and Centrohelea sp.) were observed in the water column. Only the last species was characteristic for this type of microbiotope. Three species (Acanthocystis spinosa, Raphidiophrys ovalis, and Raineriophrys echinata) were associated with Sphagnum, and two of them (underlined) were found only in this type of microbiotope. Two species, Acanthocystis mikrjukovii and Raineriophrys echinata, were observed in the peat, and the first one is unique here. Thus, more than half of the observed species (15) were found only in one type of microbiotope. Only five species (Acanthocystis nichollsi, A. trifurca, Raphidiophrys capitata, Raineriophrys echinata, $R$. erinaceoides) were found in two types of mircobiotopes, and Heterophrys-like organism was observed in three types of microbiotopes, although the last 
one can represent a stage of the life cycle in several centrohelid species. Sphagnobiont and peat communities of centrohelids are more similar to each other by species composition (Fig. 8) in comparison with plant debris and silt, sand, and water column cenoses. As a result, communities from benthic microhabitats are grouped together and differ from the water column cenoses. Therefore, we can assume that most centrohelid species are highly adapted and specialized to certain environmental microbiotopical conditions, but more research is needed.

Although current sampling is clearly incomplete, analysis of the distribution of species in water bodies has revealed some patterns. Lakes were characterized by a rather high species diversity (16 species, 4.6 species on average) in comparison with sphagnum bogs and the river and terrace forest lakes have a greater species diversity in comparison with floodplain lakes. Fifteen species (6.0 species on average) were observed in forest lakes and 10 of them were found only here (Acanthocystis aff. amura; A. costata; A. nichollsi; A. penardi; A. turfacea; Raphidiophrys capitata; $R$. intermedia; Raphidocystis symmetrica; Pterocystis pulchra; Choanocystis aculeata). While 5 species ( 2.5 species on average) were observed in floodplain lakes. Plate scales of single cell of unidentified Centrohelea sp. were found in this type of the water body. Four species were found in the river, and three of them (Acanthocystis elenazhivotovae; A. pectinata; Pterocystis foliacea) were found only here.

Sphagnum bogs with low $\mathrm{pH}$ and mineralization were characterized by low and unique species composition of heliozoans. No similarity was found between bogs and other types of habitats (Fig. 9). Species composition in lakes and river were more similar to each other. Thus, four species (Acanthocystis mikrjukovii, A. spinosa, Raphidiophrys ovalis, and Raineriophrys echinata) were found in the bogs, and all of them are unique for this type of habitat. Sphagnum parcels of the bogs can dry up almost completely in some years and are characterized by sharp daily fluctuations of temperature during these periods, resulting in a peculiarity of such type of the biotope. Known surveys on the species diversity of heterotrophic flagellates in acidified habitats also show the greatest originality of the species composition in such water bodies in comparison to neutral pH waters (Mazei et al. 2005, Prokina and Mylnikov 2017, Prokina unpubl. data). These results confirm known observation for other organisms, indicating that $\mathrm{pH}$ (especially its low values) exerts a significant regulating influence on the distribution of organisms in aquatic ecosystems (Zhadin 1950).
The majority of identified species are common on many continents in both the Northern and Southern hemispheres (Acanthocystis nichollsi, A. pectinata, A. trifurca, A. turfacea, Raphdiophrys intermedia, Pterocystis foliacea, Raineriophrys erinaceoides, R. fortesca, Choanocystis aculeata) (Nicholls 1983; Dürrschmidt 1985, 1987a; Croome 1986; Croome et al. 1987; Siemensma and Roijackers 1988a; Mikrjukov 1993a, b, etc.). Seven species were found only in the Northern hemisphere (Acanthocystis aff. amura, A. costata, A. elenazhivotovae, A. mikrjukovii, A. spinosa, Raphidocystis symmetrica, Raineriophrys echinata) (Nicholls and Dürrschmidt 1985; Siemensma and Roijackers 1988a, b; Ikävalko et al. 1996; Cavalier-Smith and von der Heyden 2007; Leonov and Plotnikov 2009; Leonov 2009, 2010a, b; Leonov and Mylnikov 2012; Zlatogursky 2015; Prokina et al. 2017c; Zlatogursky et al. 2017). All of them (except Raineriophrys echinata) were previously found only in Europe.

Many centrohelid species were previously observed in different climatic zones (tropics, subtropics, temperate, and cold polar). Six species (Acanthocystis nichollsi, A. pectinata, A. penardi, A. turfacea, Raineriophrys erinaceoides, and $R$. fortesca) were recorded in all types of climatic zones. Acanthocystis trifurca, Raphidiophrys intermedia, and Choanocystis aculeata were previously found in all types of climatic zones, except the tropics, and Pterocystis foliacea was not found in cold polar regions. Raphidiophrys ovalis and Pterocystis pulchra were found in temperate and subtropical zones whereas Raphidocystis symmetrica and Raineriophrys echinata were identified in temperate and cold polar zones. The rarest of the observed species (Acanthocystis aff. amura, A. costata, A. elenazhivotovae, A. mikrjukovii, A. spinosa, and Raphidiophrys capitata) were found only in temperate climatic zones (Cavalier-Smith and von der Heyden 2007, Leonov 2010b, Zlatogursky 2015, Zlatogursky et al. 2017), but all of these species were described recently.

Thus, all of the observed species were previously reported from temperate zones, seven species from the tropics, and twelve and eleven species were observed in subtropic and cold polar zones, respectively. The lower species diversity of centrohelids in the tropics can be explained by insufficient studies of this region in comparison with the others, rather than by the presence of poor conditions for these organisms. The same assumption can explain the high occurrence of centrohelids in the temperate zone since the most studies were conducted there. 
Although the data are currently insufficient for an in-depth analysis and broad-scale inter-regional comparisons, the revealed features in the geographical distribution of observed morphospecies confirm the cosmopolitism of centrohelids. However, it is hard to say how centrohelid diversity is distributed globally at the level of phylotypes, and how much the pattern described above would change with regards to the molecular phylotype diversity. Observed distributional patterns also highlight the importance of the type of water body and microbiotope in forming the species composition. The obtained data on the morphology of studied scales supplement our knowledge of the intraspecific variability of centrohelid heliozoans. Most of the observed species are new for water bodies of the Middle Russian forest-steppe which is most likely caused by insufficient sampling in the studied territory and potentially may indicate a species diversity of centrohelids.

Acknowledgments. This work was supported by the Russian Science Foundation (grant No 18-14-00239). The authors are grateful to Nicholas Irwin for language improvement.

\section{REFERENCES}

Adl S. M., Bass D., Lane C. E., Lukeš J., Schoch C. L., Smirnov A. et al. (2019). Revisions to the classification, nomenclature, and diversity of eukaryotes. J. Eukaryot. Microbiol. 66: 4-119.

Biyu S. (2000) Planktonic protozooplankton (ciliates, heliozoans and testaceans) in two shallow mesotrophic lakes in China a comparative study between a macrophyte-dominated lake (Biandantang) and an algal lake (Houhu). Hydrobiologia. 434: $151-163$

Burki F., Kaplan M., Tikhonenkov D. V., Zlatogursky V., Minh B. Q., Radaykina L.V., Smirnov A., Mylnikov A. P., Keeling, P. J. (2016). Untangling the early diversification of eukaryotes: a phylogenomic study of the evolutionary origins of Centrohelida, Haptophyta and Cryptista. Proc. R. Soc. B: Biol. Sci. 283: 20152802.

Cavalier-Smith T., von der Heyden S. (2007) Molecular phylogeny, scale evolution and taxonomy of centrohelid heliozoan. Mol. Phylogenet. Evol. 44: 1186-1203

Charubhun B., Charubhun N. (2000) Biodiversity of freshwater protozoa in Tailand. Kasetsart J. (Nat. Sci.). 34: 486-494

Croome R. L. (1986) Observations of the Heliozoan Genera Acanthocystis and Raphidocystis from Australia. Arch. Protistenkd. 131: 189-199

Croome R. L. (1987) Observations of the genera Acanthocystis, Raphidiophrys, Clathrulina and Pompholyxophrys (Protozoa, Sarcodina) from Australian freshwaters. Arch. Protistenkd. 133: 237-243

Croome R. L., van den Hoff J., Burton H. R. (1987) Observations of the heliozoean genera Pinaciophora and Acanthocystis (Heiliozoea, Sarcodina, Protozoa) from Ellis Fjord, Antarctica. Polar Biol.: 23-28

Dürrschmidt M. (1985) Electron microscopic observations on scales of species of the genus Acanthocystis (Centrohelidia, Heliozoa) from Chile, I. Arch Protistenkd. 129: 55-87
Dürrschmidt M. (1987a) An electron microscopical study of freshwater heliozoa (genus Acanthocystis, Centrohelidia) from Chile, New Zealand, Malaysia and Sri Lanka, II. Arch. Protistenkd. 133: 21-48

Dürrschmidt M. (1987b) An electron microscopical study on freshwater heliozoa (genus Acanthocystis, Centrohelidia) from Chile, New Zealand, Malaysia and Sri Lanka, III. Arch. Protistenkd. 133: 49-80

Ermolenko E. A., Plotnikov A. O. (2013) Ecology of centrohelid heliozoa in the Southern Urals reservoirs. Bull. Orenburg State Univ. 10: 119-121

Gaponova L. (2008) The centrohelid heliozoans (Protista, Centrohelida) of algal mats from the water body in Ukrainian Polissya. Vestnik Zoologii 42: e-38-e41

Gerasimova E. A., Plotnikov A. O. (2015) A variety of amoeboid protists in saline reservoirs of the Orenburg Region. Bull. Orenburg State Univ. 10: 130-133

Hammer Ø., Harper D. A. T., Ryan P. D. (2001) PAST: Paleontological statistics software package for education and data analysis. Palaeontologia Electronica. 4: 9pp.

Ikävalko J., Thomsen H. A., Carstens M. (1996) A preliminary study of NE Greenland shallow meltwater ponds with particular emphasis on loricate and scale-covered forms (Choanoflagellida, Chrysophyceae sensu lato, Synurophyceae, Heliozoea), including the descriptions of Epipyxis thamnoides sp. nov. and Pseudokephyrion poculiforme sp. nov. (Chrysophyceae). Arch. Protistenkd. 147: 29-42

Khlyzova N. Yu., Prokin A. A., Starodubtseva E. A., Govorov V. V, Tkachenko A. V. (2007) Materials for the study of terraced reservoirs of the Usman' and Khrenovsky boars (I): distribution, origin, anthropogenic transformation, typology, cyclicity of the hydrological regime. Proc. Voronezh State Reserve. XXIV: 234-289

Kosolapova N. G., Mylnikov A. P. (2015) First records of centrohelid heliozoans (Centrohelida) in Mongolia. Inland Water Biol. 8: $232-235$

Leonov M. M. (2010b) New species of centrohelid Heliozoa of the genus Acanthocystis (Centroheliozoa). Zool. Zhurn. 89: 507513

Leonov M. M. (2009) Heliozoan fauna of waterbodies and watercourses of the Central Russian Upland forest-steppe. Inland Water Biol. 2: 6-12

Leonov M. M. (2010a) Heliozoans (Heliozoa, Sarcodina, Protista) of fresh and marine waters of the European part of Russia: Species composition, morphology, and distribution. Inland Water Biol. 3: 344-355

Leonov M. M., Mylnikov A. P. (2012) Centroheliozoa from Southern Karelia. Zool. Zhurn. 91: 515-515

Leonov M. M., Plotnikov A. O. (2009) Species composition, morphology, and distribution of centrohelid heliozoa from Central Chernozem Region and the South Urals. Zool. Zhurn. 88: 643653

Mazei Y. A., Tikhonenkov D. V., Mylnikov A. P. (2005). Distribution of heterotrophic nanoflagellates in small freshwater bodies of Yaroslavl region. Biologiia Vnutrennikh Vod. 4: 23-29

Mikrjukov K. A. (1993a) Observations on Centroheliozoa of the Volga basin (Protozoa: Sarcondina). Zoosystematica Rossica. 2: 201-209

Mikrjukov K. A. (1993b) On the Centrohelid and Rotosphaerid Heliozoa from the environs of the Vorrtsjärv limnological station in Estonia. In Proc. Estonian Acad. Sci. 42: 154-160 
Mikrjukov K. A. (1999) Interesting findings of heliozoan (Protista) in the Black Sea and Crimea: data on the similarity of sea and freshwater fauna of these organisms. Russian J. Zool. 3: 240-249

Mikrjukov K. A. (2001) Heliozoa as a component of marine microbenthos: a study of heliozoan of the White Sea. Ophelia. 54: $51-73$

Mikrjukov K. A. (2002) Centrohelid heliozoans (Centroheliozoa). Moscow: KMK Sci. Press

Moestrup Ø., Thomsen H. A. (1980) Preparations of shadow cast whole mounts. Handbook of Phycological Methods.: Cambridge Univ. Press, Cambridge. 385-390

Nicholls K. H. (1983) Little-known and new heliozoeans: the centrohelid genus Acanthocystis, including descriptions of nine new species. Can. J. Zool. 61: 1369-1386

Nicholls K. H., Dürrschmidt M. (1985) Scale structure and taxonomy of some species of Raphidocystis, Raphidiophrys, and Pompholyxophrys (Heliozoea) including descriptions of six new taxa. Can. J. Zool. 63: 1944-1961

Plotnikov A. O., Gerasimova E. A. (2017) Heliozoa (Centrohelea, Haptista, Hacrobia) of saline and brackish water bodies and watercourses of Russia. Inland Water Biol. 10: 121-129

Plotnikov A. O., Ermolenko E. A. (2015) Centrohelid heliozoa (Chromista, Hacrobia) of Southern Cis-Ural region. Biol. Bull. 42: 683-695

Prokina K. I., Mylnikov A. P. (2019) Centrohelid heliozoans from freshwater habitats of South Patagonia and Tierra del Fuego, Chile. Inland Water Biol. 1: 12-22

Prokina K. I., Mylnikov A. A., Mylnikov A. P. (2017a) Heterotrophic flagellates and centrohelid heliozoan from littoral and supralittoral zones of the Black Sea (the Southern part of the Crimea). Protistology 11: 143-169

Prokina K. I., Mylnikov A. P., Zelalem W. (2017b) First data on heterotrophic flagellates and helozoans of Ethiopia. Biol. Bull. 44: 896-912

Prokina K. I., Zagumyonnyi D. G., Philippov D. A. (2017c) Centrohelids in the mires of Northern Russia. Protistology 11: 3-19

Siemensma F. J., Roijackers R. M. M. (1988a) A study of new and little-known acanthocystid heliozoeans, and a proposed division of the genus Acanthocystis (Actinopoda, Heliozoea). Arch. Protistenkd. 135: 197-212

Siemensma F. J., Roijackers R. M. M. (1988b) The genus Raphidiophrys (Actinopoda, Heliozoea): scale morphology and species distinctions. Arch. Protistenkd. 136: 237-248

Takamura N., Shen Yu., Xie P. (2000) Species richness of protozoa in Japanese lakes. Limnology 1: 91-106

Tikhonenkov D.V., Mylnikov A.P. (2011) Choanocystis antarctica sp. n., a new heliozoan (Centrohelida) species from the littoral zone of King George Island, South Shetland Islands, Antarctica. Biol. Bull. 38: 663-666

Vørs N. (1992) Heterotrophic amoebae, flagellates and heliozoan from the Tvärminne area, gulf of Finland, in 1988-1990. Ophelia. 36: $1-109$

Wujek D. E. (2006) Freshwater heliozoa from Florida. Florida Scientist. 69: 177-191

Wujek D. E., Fritz B. A., Dziedzic R. M. (2010) Silica-scaled Chrysophytes and Heliozoa from the Caribbean Islands of Dominica (Lesser Antilles). Caribbean J. Sci. 46: 120-123

Wujek D. E. (2003) Freshwater scaled heterotrophic protistans from four gulf states, including descriptions of two species. J. Alabama Acad. Sci. 74: 164-181

Wujek D.E. (2005) Identification, ecology, and distribution of scale bearing amoeba, ciliates, flagellates and heliozoan from the Carolinas. J. North Carolina Acad. Sci. 121: 1-16

Wujek D. E., Ogundipe O. T. (2002) Heliozoa from Nigeria. Trop. Freshwat. Biol. 11 (1): 1-9

Wujek D. E., Saha L. C. (2006) Freshwater scaled heterotrophic flagellates and heliozoan from India including a description of a new species of Choanocystis. J. Bombay Nat. Hist. Soc. 103: $71-81$

Yabuki A., Chao E. E., Ishida K. I., Cavalier-Smith T. (2012) Microheliella maris (Microhelida ord. n.), an ultrastructurally highly distinctive new axopodial protist species and genus, and the unity of phylum Heliozoa. Protist. 163: 356-388

Zhadin V. I. (1950) Features of various freshwater bodies. Life of freshwaters of the USSR. 3: 11-19

Zhivotova E. N., Koroteeva O. A. (2002) The study of the hydrochemical regime of some water bodies of the Usman' Pine Forest. Hydrobiological Studies of Water Bodies of the Central Russian Steppe. 1: 221-228

Zlatogursky V. V. 2015. Two new species of Centrohelid Heliozoans: Acanthocystis costata sp. nov. and Choanocystis symna sp. nov. Acta Protozool. 53: 313-324

Zlatogursky V. V., Drachko D., Klimov V. I., Shishkin Y. (2018) On the phylogenetic position of the genus Raphidocystis (Haptista: Centroplasthelida) with notes on the dimorphism in centrohelid life cycle. Eur. J. Protistol. 64: 82-90

Zlatogursky V. V., Gerasimova E. A., Plotnikov A. O. (2017) A new species of Centrohelid Heliozoan Acanthocystis amura n. sp. isolated from two remote locations in Russia. J. Euk. Microbiol. 64: $434-439$

Received on $14^{\text {th }}$ October, 2018; revised on $10^{\text {th }}$ December, 2018; accepted on $13^{\text {th }}$ December, 2018 
264 K. I. Prokina et al.

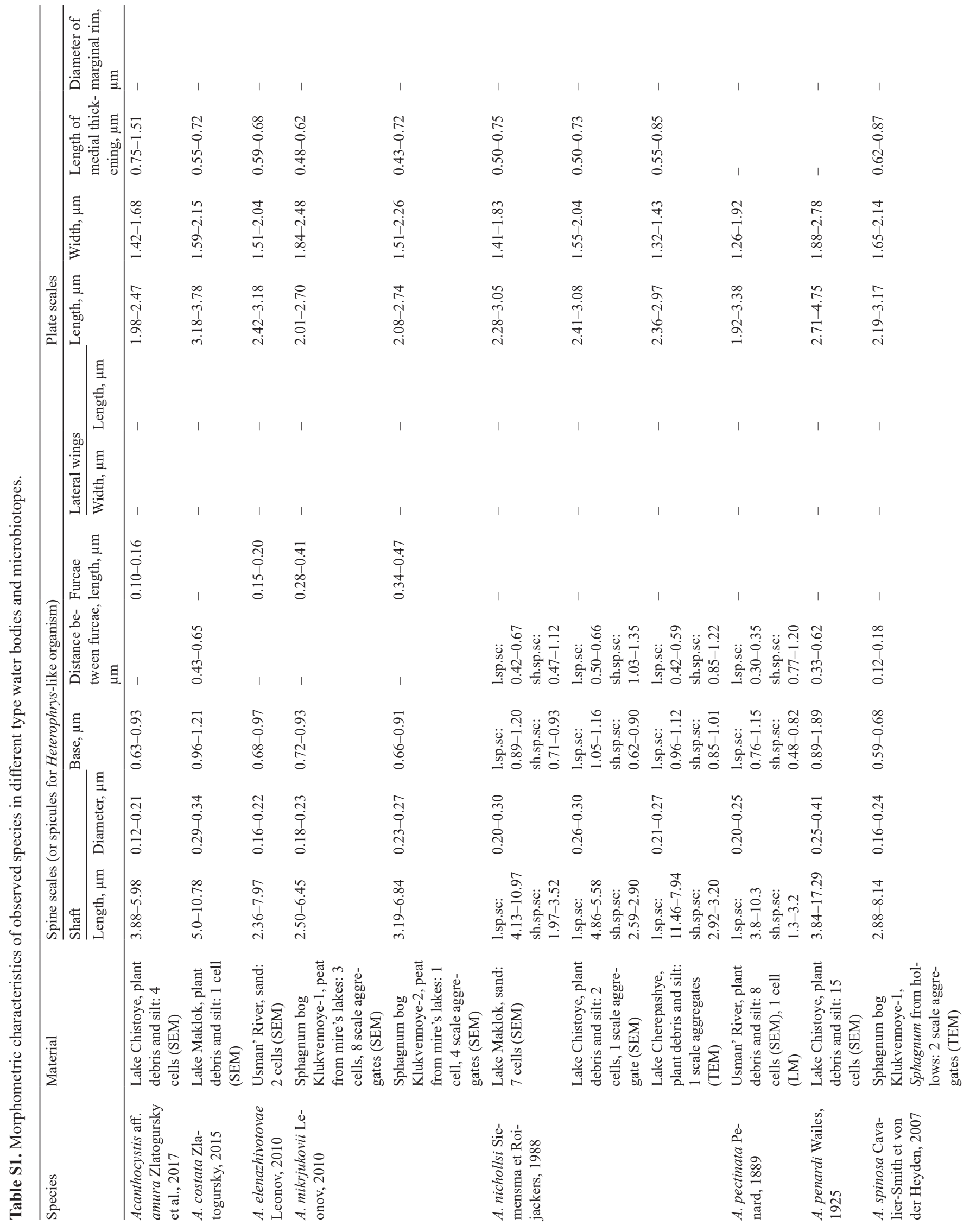




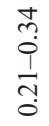

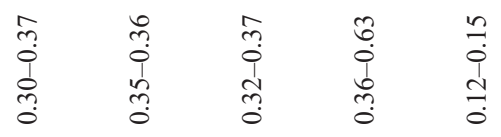

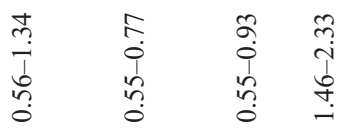

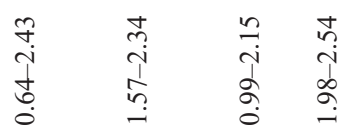

$a$
$\dot{p}$
$b$
$i$
i

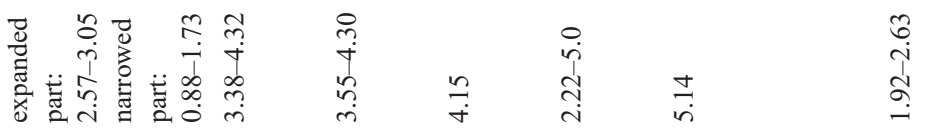

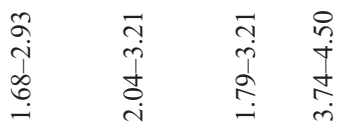

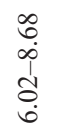

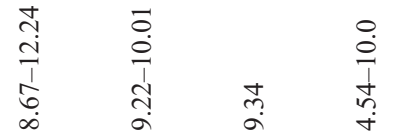

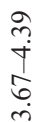

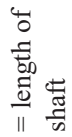

$\underset{\substack{n \\ \stackrel{n}{i}}}{\stackrel{i}{二}}$

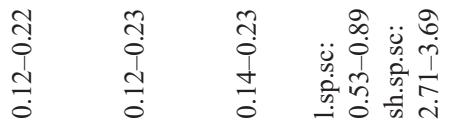

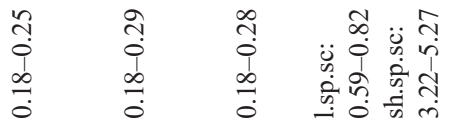

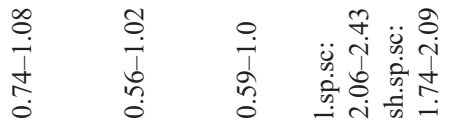

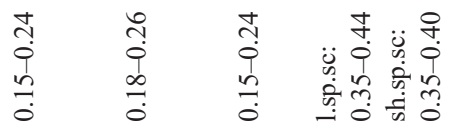

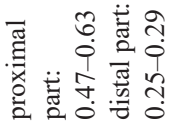

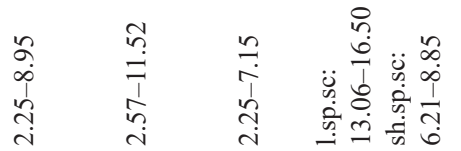

în.

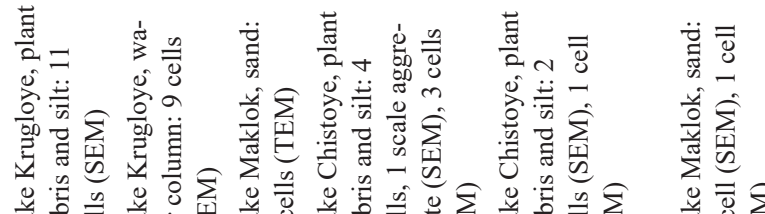

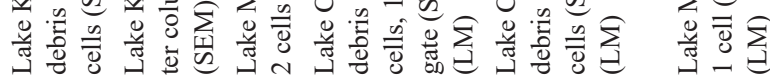

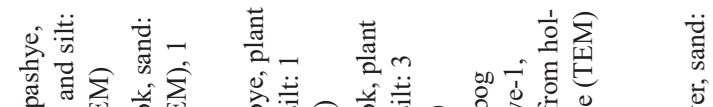

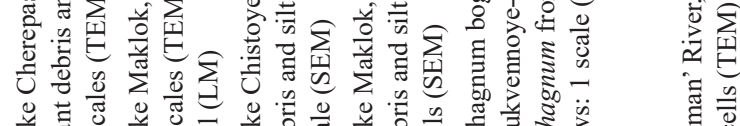

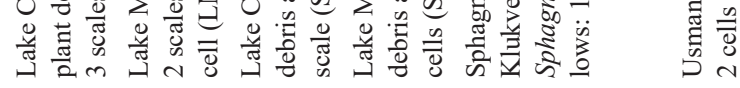

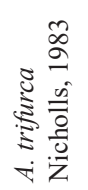

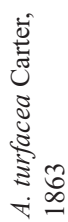

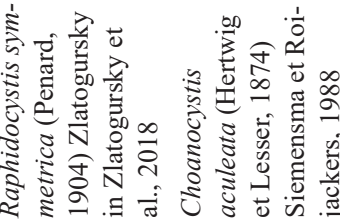

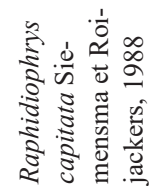

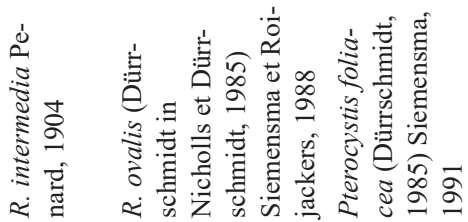


266 K. I. Prokina et al.

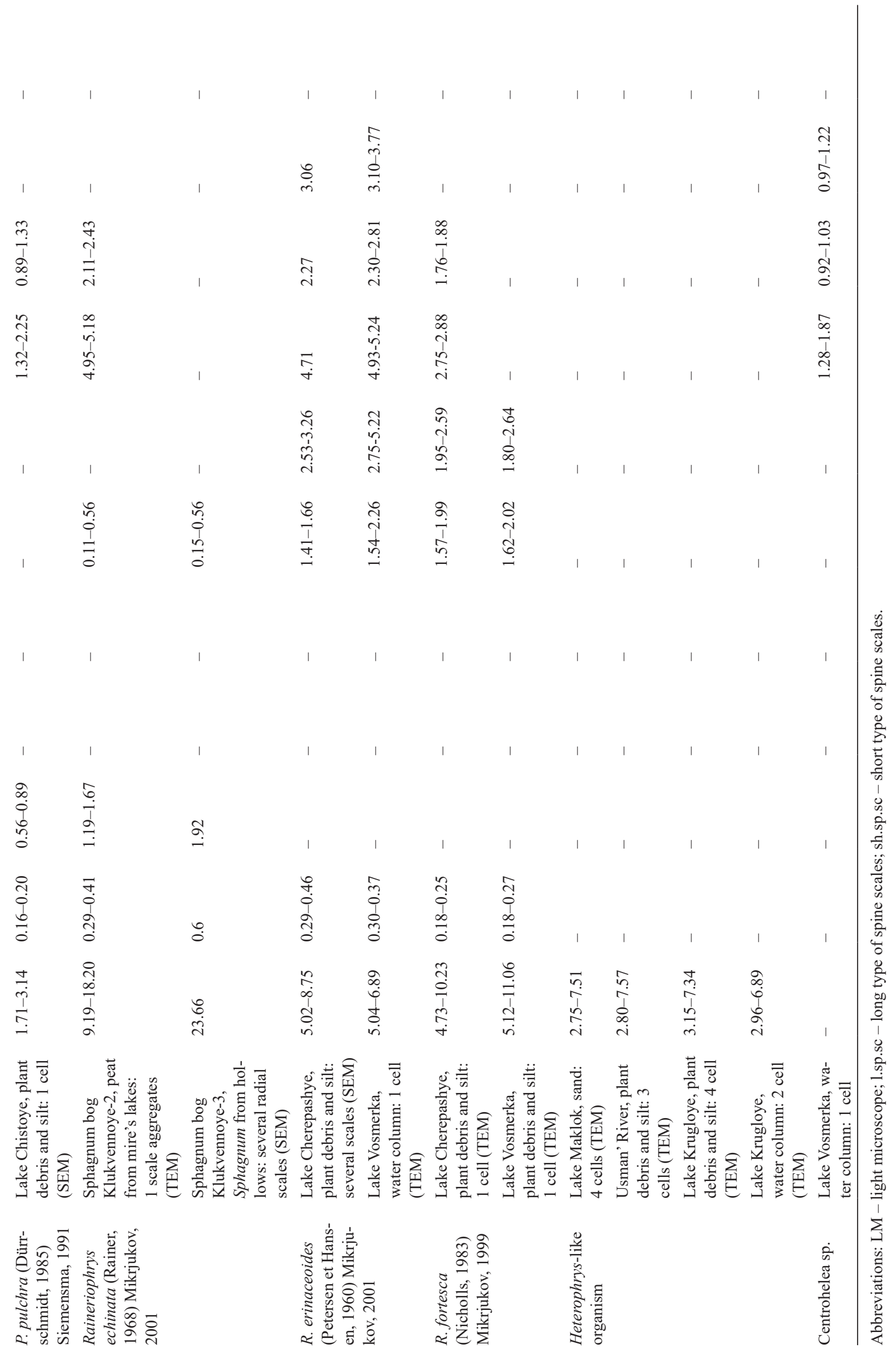

